\title{
VISIÓN Y TRATAMIENTO DEL PECADO EN LOS MANUALES DE CONFESIÓN DE LA BAJA EDAD MEDIA HISPANA*
}

\author{
POR \\ José MARÍA Soto RÁBANOS \\ Instituto de Historia, CSIC. Madrid
}

\begin{abstract}
RESUMEN
La confesión oral se constituye en el eje de la acción pastoral durante la baja edad media. El pecado, por ello, ocupa un lugar de privilegio en el quehacer cotidiano, tanto en el aspecto de su confesión como en el de su satisfación. Al efecto, se elaboran tratados para los curados y también, ya en el siglo XV, para los fieles. En este trabajo se detallan las características generales de doce tratados de confesión, escritos en latín y en varias lenguas romances, y se analiza la visión y el tratamiento del pecado, considerando seis aspectos: la noción de pecado; la ignorancia como protección frente al pecar; las clases de pecados; qué pecados se deben someter a la confesión; la notoriedad como agravante objetiva del pecado que lleva a una cierta desteologización del mismo; y la confesión como instrumento para el control de los fieles.
\end{abstract}

PALABRAS ClAVE: Acción pastoral. Tratados de confesión. Pecados. Ignorancia. Notoriedad. Control social.

\section{ABSTRACT}

The oral confession became the central idea of the pastoral activity during the Late Middle Ages. That is why sin gets a privileged place in the daily task, in what affects its confession and its satisfaction. To this effect, treatises were written for the priests and, in the fifteenth century, also for the faithful. In this article the author informs in detail about the general characteristics of twelve treatises of confession, written in Latin and in several Romance languages, and

* Este trabajo ha sido elaborado en el curso de investigaciones relativas al proyecto El discurso político-religioso en la sociedad castellana bajomedieval. Elaboración y difusión, financiado por la Dirección General de Investigación. 
he analyses their vision and treatment of the problematic of sin, taking into account six different aspects: the notion of sin; ignorance as a means of protection against sin; the typology of sins; the sins that must be confessed; notoriety as an objective aggravating factor for sin, that conveys a certain loss of theological value for it; and confession as an instrument for the control of the faithful.

KEY WORDS: Pastoral Action. Treaties of Confession. Sins. Ignorance. Notoriety. Social Control.

\section{PRELIMINARES}

Los tratados que voy a tener especialmente en cuenta representan la variedad de escritos que se pusieron o se trataron de poner al alcance de los curados y de los fieles sobre el tema del pecado y de la consecución del perdón durante los siglos XIV y XV. En el siglo XV asistimos a un gran florecimiento de esta clase de obras en la Península Ibérica.

La expresión manuales de confesión que figura en el título la utilizo aquí en sentido amplio, incluyendo también en ella, además de los tratados o modos de confesión propiamente dichos, algunos manuales de curados, que se proponen atender a los clérigos con cura de almas en todos los aspectos de la práctica pastoral, sea en la administración de los sacramentos, sea en la celebración del culto, sea en la instrucción de la doctrina cristiana ${ }^{1}$. La razón es que la administración del sacramento de la penitencia ocupa en la mayoría de estos manuales, si no en todos, un lugar preferente. En un confesional anónimo, que se conserva en el Ms. d. IV. 2, ff. 33ra-45rb, de la Real Biblioteca de San Lorenzo del Escorial, con letra del siglo XIV en estimación del autor del catálogo, Guillermo Antolín², se llega incluso a identificar con naturalidad la cura animarum con la cognitio peccatorum, es decir, la atención total pastoral a los fieles con el discernimiento de los pecados en orden a la obtención del perdón. Se expresa la equiparación en el título dado al tratado: «Prologus super libello qui dicitur informatorius simplicium sacerdotum in cura animarum, hoc est, in cognitione peccatorum» [Prólogo sobre el librito que se titula informativo de sacerdotes con pocos conocimientos en la cura de almas, es decir, en el discernimniento de los pecados] $]^{3}$.

${ }^{1}$ Es el triple contenido de la cura de almas que pone de relieve el concilio Lateranense IV en su constitución n. 9: «... districte praecipimus ut pontifices... provideant viros idoneos qui... divina officia illis celebrent et ecclesiastica sacramenta ministrent, instruendo eos verbo pariter et exemplo» [mandamos severamente que los obispos provean (a las iglesias) de hombres idóneos que celebren (a los fieles) los oficios divinos, administren los sacramentos e instruyan con la palabra e igualmente con el ejemplo].

2 Guillermo Antolín, Catálogo de los Códices latinos de la Real Biblioteca del Escorial, 1 (Madrid, 1910) p. 502.

${ }^{3}$ F. 33ra. Esta misma frase se repite al final, en f. 45rb: «Explicit libellus qui dicitur informatorius simplicium sacerdotum in cura animarum, hoc est, in cognitione peccatorum». El MS contiene algunas piezas en italiano, lo que hace pensar en la posibilidad de que esta obra haya sido elaborada en Italia.

Hispania Sacra, LVIII

118, julio-diciembre 2006, 411-447, ISSN: 0018-215-X 
Otro buen ejemplo es el Manipulus curatorum (libro de mano, o vademécum, de curados) de Guido de Monte Roterio. Guido divide su obra en tres partes, reservando una de ellas, la segunda, para el sacramento de la penitencia. En la primera parte trata de los sacramentos en general y de los otros seis sacramentos, y en la tercera de lo que toca a la instrucción cristiana ${ }^{4}$. La parte central, con más de un tercio de la extensión total del tratado, 30 folios aproximadamente de un total de 86 , del folio 45rb al 75ra, está ocupada por el sacramento de la penitencia. La primacía de este sacramento se razona por el hecho de que el oficio de oír las confesiones de los fieles tiene entidad propia dentro de las obligaciones sacerdotales. El ministerio de los sacerdotes, especialmente de los que tienen cura de almas, consiste en cuatro cosas: celebrar misa, administrar sacramentos, oír confesiones e informar al pueblo en los artículos y demás rudimentos de la fe ${ }^{5}$. Es decir, Guido no se conforma con incluir la penitencia entre los sacramentos; lo destaca y le concede entidad aparte.

No es difícil comprender esta situación de primacía, si tenemos en cuenta que, a partir del concilio IV de Letrán del año 1215, la penitencia es el gran sacramento, en torno al cual gira la vida moral de los fieles y la acción pastoral de la Iglesia. Resulta, pues, lógico que esta mentalidad se manifieste abiertamente en la literatura destinada a la práctica pastoral.

En efecto, los manuales de confesión y los vademécum de los rectores de almas de estos siglos XIV y XV, y los de los siglos posteriores hasta nuestros días, responden al modelo de practicar el sacramento del perdón impuesto por la famosa constitución 21 del concilio IV de Letrán de 1215, que empieza con las palabras: Omnis utriusque sexus fidelis. No mucho antes, a mediados del siglo XII, cuando el monje Graciano publicaba su Decreto, se discutía aún entre los teólogos sobre la necesidad de la confesión oral secreta. Graciano plantea la cuestión y la deja sin resolver en uno u otro sentido, señalando que ambas teorías presentan buenos argumentos de autoridad y de razón a su favor, por lo que

4 F..2ra: «Diuiditur autem presens opusculum in tres partes, in quarum prima agitur de sacramentis et de his que pertinent ad sacramentorum administrationem. In secunda de penitentiis et de his que pertinent ad confessionem audientiam et penitentiam impositionem. In tertia de fidei articulis et de his que pertinent ad populi informationem». Utilizo el incunable 61-VII-19, n. 2 de la Real Biblioteca de San Lorenzo del Escorial. El ejemplar no está numerado; la numeración indicada es la que le corresponde como obra aparte, con paginación propia, dentro del incunable. El número 1 del incunable contiene una obra del mismo género que el Manipulus compuesta por Nicolás de Plove, doctor en Decretos y capellán del obispo Estanislao de la diócesis posnoniense (Poznan, Polonia), que ocupa 120 folios con numeración romana. Se observa, además, que los responsables de esta edición incunable [Venetiis, 1493], o no tenían conocimiento suficiente del latín, o no revisaron bien el texto, puesto que contiene claras incorrecciones sintácticas, como puede apreciarse en el texto incluido en esta misma nota; concretamente, en la frase: que pertinent ad confessionem audientiam et penitentiam impositionem..

5 F. 122va-122vb: «Officium autem sacerdotum, maxime curatorum, consistit in quattuor secundum quattuor ethimologias istius nominis..., quia sacerdotes sunt missarum celebratores... sacrorum ministratores..., confessionum auditores..., doctores». 
en la práctica tendría aplicación la conocida máxima in dubiis libertas ${ }^{6}$. Reconoce, no obstante, Graciano que la opinión más generalizada estaba a favor de la obligatoriedad de la confesión oral al sacerdote 7 . De otra parte, no es gratuito suponer que cuando el concilio citado impone la obligatoriedad sub gravi de la confesión oral como forma sacramental de obtener el perdón de los pecados está atendiendo a la reglamentación de una práctica común. No olvidemos, tampoco, que para aquellos tiempos, la confesión oral secreta con la penitencia igualmente secreta para los pecados asimismo secretos, impuesta a discreción o buen saber y entender del confesor, habida cuenta de lo confesado y del confesante, suponía un claro progreso sobre las formas anteriores de penitencia solemne y pública, y según tarifas, un progreso marcado por la privacidad y por una atención más personalizada.

Una mirada atrás, a lo largo de la historia conocida de la humanidad, pone de manifiesto la existencia de una lenta pero clara evolución en el concepto y en la calificación socio-moral de los actos humanos. Y no se trata sólo de un cambio en las formas, sino de un cambio de fondo en la mentalidad con la que se valoran los actos humanos en su contexto moral; los mismos actos llegan a merecer alabanza o castigo, aprecio, menosprecio o indiferencia, conforme a consideraciones relativas. Así nos lo enseña la historia contemplada a distancia, aunque vista día a día pueda parecer que apenas cambia. La guerra llega a ser considerada una acción legítima por razones de fe (cruzadas cristianas) y aún hoy es legitimada por esta causa en algunas sociedades que predican y practican a su manera la guerra santa. La esclavitud, en sentido propio, fue considerada durante mucho tiempo como algo natural, por la sociedad y por los teólogos cristianos, los cuales, si bien defendían la igualdad radical humana ante Dios, admitían con naturalidad razones justificativas de la esclavitud de muchos humanos. Y estos no son más que dos grandes ejemplos.

En este sentido, Polibio (ca. 210 - ca. 128 a.C.) señalaba certeramente el relativismo de los juicios morales: «...dar muerte a los ciudadanos es tenido como sacrilegio máximo, como crimen digno de los más refinados suplicios. Y, sin embargo, es notorio que el que ejecuta a un ladrón o a un adúltero goza de impunidad, y el que mata a un traidor o a un tirano merece un asiento de honor a la

${ }^{6}$ De poen D.1 c.89 [Friedberg I, 1189]: «Quibus auctoritatibus, uel quibus rationum firmamentis utraque sententia confessionis et satisfactionis nitatur, in medium breuiter proposuimus. Cui autem harum potius adherendum sit, lectoris iudicio reseruatur. Utraque enim fautores habet sapientes et religiosos viros» (Hemos expuesto brevemente las autoridades y los argumentos de razón en que se apoyan una y otra opinión sobre la confesión y la satisfacción. Mas, a cual de ellas es mejor adherirse, se reserva al juicio del lector, pues ambas tienen por defensores a varones prudentes y piadosos).

7 De poen D.1 c.90 [Friedberg I, 1189]: «Quidam Deo solummodo confiteri debere peccata dicunt, ut Graeci. Quidam uero sacerdotibus confitenda esse percensent, ut fere tota sancta ecclesia» [Algunos afirman que los pecados se deben confesar solamente a Dios, como los griegos. Otros, sin embargo, consideran que se han de confesar a los sacerdotes, como casi toda la santa iglesia]. 
vista de todos. Así, la emisión de un juicio definitivo no debe basarse nunca en los hechos en sí, antes bien, en sus causas y en las razones que movieron a sus autores; también en las diferencias que ellas presentan» ${ }^{8}$.

La reflexión se aplica perfectamente a nuestro caso: los pecados capitales en la baja edad media. En el periodo que consideramos, los vicios o pecados capitales son una institución, que se va a consolidar durante estos siglos bajomedievales. Entre el concilio IV de Letrán (1215) y el concilio de Trento (1545-1563) hay una evolución teológica de desarrollo, que se manifiesta en la creación de formulaciones filosófico-teológicas (corrientes escolásticas) y de normas jurídico-canónicas, que dan lugar al Corpus Iuris Canonici. La teología y el derecho se encuentran, casi siempre, pero no siempre, con la misma opinión, en la literatura pastoral, que viene a ser en un porcentaje alto una literatura del y sobre el pecado.

El pecado es el leit-motiv de la literatura pastoral. Si en alguna literatura se expresa con mayor claridad este dominio de la conciencia del cristiano de ser culpable y de la necesidad de ser exculpado y salvado por un poder superior es, sin duda, en la literatura ad hoc, o sea, en los manuales de confesión, que hallan su justificación precisamente en la conciencia de ser pecador y en la necesidad religiosa, y psicológica, de ser perdonado. En ello insisten los tratadistas. No otro pensamiento anidaba, por ejemplo, en Sebastián de Ota cuando en el proemio al Tractatus de confessione dice que la confesión es el ejercicio espiritual máximo entre los que sirven para la salvación de las almas ${ }^{9}$.

El pecado es, por tanto, el protagonista principal de los tratados de confesión, por encima del confesor, del penitente y del propio sacramento. En principio, parecería que el primer protagonista debiera ser el sacerdote confesor, que figura como destinatario directo ${ }^{10}$; o bien, el penitente, que es, al fin y al cabo, el sujeto y beneficiario del sacramento de la confesión, sea o no co-destinatario de la obra, puesto que es quien se confiesa; o también, el sacramento mismo de la penitencia con todo su contenido, pues es lo que se pone en juego. Y, en verdad, todos estos elementos tienen una cuota importante de protagonismo, porque todos ellos se toman como partes esenciales en los escritos; pero, cuando se detiene uno a reflexionar, acaba convencido de que el actor que sobresale, el gran protagonista, es el pecado.

\footnotetext{
${ }^{8}$ Historias, libro II, §.56, Biblioteca Clásica Gredos, Introducción de A. DíAZ TeJERA. Traducción y notas de M. BALASCH RECORT, 1. a reimpresión, Madrid, 1991, p. 254.

${ }^{9}$ Incunable (Sevilla 1497), f. 2 r.

${ }^{10}$ Concretando más, se puede afirmar que el destinatario de estas obras es el sacerdote curado simple, es decir, con conocimientos insuficientes para llevar a cabo dignamente su tarea de administrador del sacramento de la penitencia. Es este un dato que se repite en la causa motiva de todos los manuales.
} 
Cierto es, por lo demás, que la atención al pecado por parte del rector de almas es, y debe ser, constante a lo largo del año cristiano; no se limita al acto de la confesión, pero este acto es el momento cumbre.

Los fieles, en efecto, son bombardeados día a día, minuto a minuto, con normas y consejos sobre el modo de conducirse. Durante el año litúrgico se intenta mantener encendida la luz de la fe cristiana con llamadas constantes de atención: la misa dominical y festiva, cuando no diaria; los sermones; la enseñanza de la doctrina a los fieles en general, y a los niños y mozos en particular; el rezo de las horas en las iglesias principales; las campanadas para el rezo del avemaría; la señal de la cruz al inicio de las labores; la visita, el viático y, en su caso, la extrema unción a los enfermos, etc. Son métodos para dar sentido cristiano a los momentos todos de la vida. Se pretende controlar cada acción; y siempre desde la idea del pecado. El cumplimiento de las obligaciones se ve desde la vertiente negati$v a$, de evitar el pecado, desde el no cumplimiento y sus consecuencias, más que desde la vertiente positiva de enriquecimiento personal en la fe ${ }^{11}$.

Se puede afirmar que no hay lugar para la neutralidad; en la práctica de la fe no se admiten actos neutros. Lo proclama el evangelio: el que no está conmigo está contra $m i^{12}$. Ello lleva a un control en todos los ámbitos de la vida cotidiana. El ejercicio del oficio o profesión de cada cual, la relación familiar, la relación social, sea entre vecinos y gentes de la misma condición, sea entre autoridades y subalternos, sea entre individuos de distinta religión (cristianos, judíos y musulmanes), la vida cotidiana, toda ella, está marcada, regulada hasta el detalle.

En definitiva, se trata de vivir en cristiano, esto es, en el dilema del bien frente al mal, de la fortuna frente al infortunio, en el dilema de la esperanza en una gloria eterna frente al temor de la condena a una muerte eterna. Así, el dualismo está servido. Y en esta situación, la confesión oral representa el rendimiento anual de cuentas, partiendo de la condición natural pecadora del hombre, es decir, de un rendimiento fatal y necesariamente negativo, al que sólo puede poner remedio el sacramento de la confesión. En él se especifican los pecados, se pide el perdón y se acepta la penitencia que estima adecuada el confesor, habida cuenta de las circunstancias del pecado y del pecador. A este respec-

11 Un dato bien significativo en este sentido lo tenemos en el sacramento de la eucaristía o comunión, en el que prima la reverencia y limpieza de alma con la que se debe recibir sobre la consideración de alimento espiritual y de fortaleza para la vida cristiana. En ese tiempo, disminuye la importancia de la comunión en la medida en que se subordina a la confesión. La obligación anual de recibir la comunión en tiempo pascual sigue a la de la confesión en tiempo cuaresmal. El sacerdote curado no dará la comunión pascual a ninguno de sus feligreses que no se haya confesado previamente. Sínodos del siglo $\mathrm{XV}$ exigen a los rectores de iglesias la confección de listas de los fieles confesados y comulgados, por este orden.

12 Mt. 12, 30.

Hispania Sacra, LVIII

118, julio-diciembre 2006, 411-447, ISSN: 0018-215-X 
to, me parece muy acertada la reflexión de Jean Delumeau sobre que, desde la perspectiva del poder, la dramatización del pecado y de sus consecuencias reforzó la autoridad del clero, llegando a ser el confesor un personaje irremplazable» ${ }^{13}$.

$\mathrm{Y}$ en el reinado del pecado, la palabra mágica es saligia. Cada una de sus siete letras es la inicial de cada uno de los siete vicios o pecados capitales o mortales, que se consideran las raíces del árbol completo de las máculas morales; toda acción reprobable desde el punto de vista de la moral cristiana, todo pecado, mortal o venial, todo pecadillo o falta, hunde sus raíces en alguno de esos siete vicios expresados en latín por la dicción mnemotécnica saligia: superbia, avaritia, luxuria, ira, gula, invidia, acidia; dicción que se acomoda casi perfectamente a las lenguas romances; por ejemplo, al castellano o al portugués: soberbia, avaricia, lujuria, ira, gula (gargantería), invidia (envidia), acidia (pereza). Estos siete vicios con sus ramificaciones son los pecados por antonomasia. Con relación a ellos no se puede afirmar que se cometen en contra, como sucede en el caso de los mandamientos, artículos de la fe, sacramentos, virtudes, obras de misericordia, etc.; simplemente se cometen, porque hacen referencia a los aspectos que el cristiano no debe asumir en absoluto: ser soberbio, lujurioso, iracundo, etc.

\section{CARACTERÍSTICAS DE LOS TRATADOS}

\section{Libro de las confesiones de Martín Pérez}

Martín Pérez, un personaje apenas conocido hasta hace unos años, escribió entre 1312 y 1317 una obra voluminosa en romance castellano, dividida en tres partes, llanada por él mismo Pobre libro de las confesiones y dirigida a los «clerigos menguados de sçiençia» ${ }^{14}$. La obra se tradujo al portugués y tuvo gran difusión, cuando menos, por las zonas central y occidental de la Península ${ }^{15}$. Martín Pérez se centra desde el principio en el pecado y en su confesión, pero lo hace detalladamente, sin dejar tema alguno por tratar, de modo que se adentra con detenimiento, no sólo en la administración del sacramento de la peniten-

13 Obra citada en nota 4, p. 9: «Certes, on peut dire, en jugeant les choses à partir de la notion de « pouvoir », que la dramatisation du péché et de ses conséquences renforça l'autorité cléricale. Le confesseur devint un personnage irremplaçable».

14 Martín PÉrez, Libro de las confesiones. Edición crítica, introducción y notas por Antonio GARCÍA y García, Bernardo Alonso Rodríguez, Francisco Cantelar Rodríguez (BAC Maior 69, Madrid, 2002), «Prólogo», p. 3: «Comiençase el pobre Libro de las confesiones, dicho asi porque es fecho e cunplido para los clerigos menguados de sçiençia, e porque es asi commo mendigado de los libros del derecho e de las escripturas de la santa teologia».

15 O.c., Introducción, pp. XXII-XXVII. 
cia, sino en el contenido todo de la doctrina cristiana. El pecado tiene largo alcance, se peca contra los mandamientos, contra los artículos de la fe, contra los sacramentos, contra las obras de misericordia, etc.

En la primera parte habla «de los pecados comunales a todos los estados». Empieza por los pecados capitales, pero en un orden distinto al de la dicción saligia; dicción que no utiliza. En los dos primeros lugares coloca los pecados de lujuria (que debiera ser el último, según nuestro autor) y de avaricia: «E non tenga ninguno por mengua porque en la ordenaçion de los pecados capitales es puesto primero el pecado de la luxuria, que devia ser postrimero, e primero el pecado de la soverbia, ca a sabiendas fue fecho porque segund dizen algunos doctores e paresçe por esperiençia, dos son los pecados en que paresçen los omes mas enbueltos, conviene a saber luxuria e cobdiçia» ${ }^{16}$. Luego trata de los pecados de soberbia, acidia-pereza, envidia, ira y gargantería-gula, por este orden. En el de soberbia introduce los mandamientos; y en el de acidia los artículos de la fe, las obras de misericordia y algunos aspectos de los sacramentos. El pecado en el que más se detiene es la avaricia (caps. 22-118; pp. 50-154); el segundo lugar, a gran distancia, lo ocupa la soberbia (caps. 119-143; pp. 154-182) y el tercer lugar la acidia (caps. 144-156; pp. 182-190). Al pecado de lujuria, sin embargo, le dedica sólo unas páginas (caps. 20-21; pp. 47-50), no porque no le dé importancia, sino porque el confesor debe usar de gran mesura al preguntar sobre él; en tan pocas páginas insiste varias veces sobre esta mesura: «... e non le demandes mas desta razon»... e non le descubras mas... e non demandes mas desto... e non demandes mas descubierto de tales cosas... non descubriendo ninguna cosa...» ${ }^{17}$.

Aunque en estos siete se encierran todos los otros pecados, Martín Pérez cree conveniente preguntar aparte, «por si». sobre algunos, concretamente sobre los de la lengua y los que dan lugar a escándalo, o sea, los que producen, o se supone que deben producir, crispación en la sociedad cristiana: «E commoquier que en estos pecados dichos se pueden ençerrar todos los otros, enpero algunos pecados son que conviene que se pongan por si por que se entiendan mejor, asi commo los pecados de la lengua e los pecados del escandalo» ${ }^{18}$.

En la segunda parte, que es algo más extensa que las otras dos, trata «de los pecados en los que caen «espeçialmente algunas personas de algunos estados señalados», comenzando por los eclesiásticos: prelados, clérigos, monjes, religiosos, y siguiendo por los seglares: reyes, príncipes, caballeros, merinos, escri-

16 «Prólogo», p. 7: Vuelve sobre esta idea al tratar del orden que debe seguir el confesor en el interrogatorio (I, 19; p. 47).

17 I, 20, pp. 48-49. No resulta acertado lo que se afirma a este respecto en la Introducción a la, por otra parte, magnífica edición de la obra: «Según era de esperar, dedica muchas páginas al pecado de la lujuria, como era bastante usual en los autores de la época» (p. XI).

18 I., 163, p. 198. 
banos, abogados, maestros, médicos, menestrales, y un largo etcétera. Al revisar cómo puede y suele pecar cada uno según su estado, va indicando las obligaciones específicas profesionales, de modo que a esta obra se la ha considerado con razón una radiografía de la sociedad de su tiempo ${ }^{19}$. Termina esta segunda parte con exhortaciones al confesor sobre la manera de actuar con el confesado: amonestar, absolver, poner penitencia; y, en especial, con el penitente enfermo.

La tercera parte la dedica el autor a una exposición bastante detallada de los sacramentos, incluyendo el sacramento de la penitencia. Martín Pérez justifica el hecho de tratar de nuevo sobre la penitencia con dos argumentos; uno formal: porque conviene guardar la ordenaçion de los sacramentos; otro material, porque conviene que se digan generalmente algunas cosas que fincaron de dezir ${ }^{20}$.

\section{Manipulus curatorum de Guido de Monte Roterio}

Pocos años después del Libro de las confesiones de Martín Pérez aparece la obra antes citada, Manipulus curatorum, de Guido de Monte Roterio, escrita en Teruel en 1333, y dedicada al obispo de Valencia, Raimundo Gastón (13121348). Fuera de lo ya anotado sobre esta obra, conviene tener en cuenta que su autor se nos presenta más como teólogo que como canonista, y ve los temas desde la óptica de la teología, a pesar de que en líneas generales en el tema del pecado y de la penitencia se apoya muy de cerca en el Decreto de Graciano y en el afamado canonista Raimundo de Peñafort. En las cuestiones disputadas entre los teólogos y los canonistas suele asumir, siempre con mucha cautela, la opinión de los teólogos ${ }^{21}$.

La parte dedicada al sacramento de la penitencia viene a ser para el propio autor un tratado de confesión destinado a los sacerdotes con cura de almas poco conocedores del derecho canónico y de la teología; por lo cual promete dejar aparte las sutilezas y ser sencillo y práctico en la exposición: «Vt igitur sacerdo[te]s curati qui non sunt multum in iure canonico uel sacra theologia prouecti aliquam notitiam haberent per quam possent inter lepram et lepram discernere... aliqua... ut melius et breuius potui compilaui...» [Con el fin de que los

19 Los editores de la obra la subtitulan acertadamente: «Una radiografía de la sociedad medieval española».

20 Parte III, cap. 35 (Ed. citada, p. 560): «Del sacramento de la penitençia non conviene mucho dezir, ca la primera parte e la segunda deste libro, amas fablan de la penitençia. Onde, commo fue dicho en el prologo, pudierase escusar en este lugar, salvo por la ordenaçion de los sacramentos. Enpero conviene que se digan generalmente algunas cosas que fincaron de dezir».

21 Por ejemplo, en la cuestión de si el número de órdenes es siete, como opinan los teólogos, o nueve, como afirman los canonistas, Guido se pone de parte de los teólogos (Incunable Escorial 61VII-19 n.2, f. 32rb-33ra). 
sacerdotes curados, que no son versados en el derecho canónico ni en la teología, puedan tener ciencia suficiente para discernir entre lepra y lepra, he compilado, como mejor y más brevemente pude, algunos saberes] $]^{22}$.

En cuanto a los pecados mortales centra enseguida el tema en los siete vicios capitales, siguiendo el orden de la dicción saligia, y en sus ramificaciones. Para tener una regla concreta y segura de los pecados mortales se ha de tener en cuenta que todos ellos se reducen a los siete vicios capitales ${ }^{23}$. La suma total es de cincuenta pecados, número del que nos habla el profeta Elías, que se distribuyen así: siete ramos de la soberbia, seis de la avaricia, ocho de la lujuria, seis de la ira, cinco de la gula, cinco de la envidia y seis de la acidia, cincuenta en total: cuarenta tres ramos más las siete raíces ${ }^{24}$. Sobre ellos deberá interrogar el confesor, variando las preguntas conforme a la diversidad de los penitentes, según que sean religiosos, clérigos seculares, príncipes, soldados, mercaderes y oficiales de artes mecánicas, hombres de ciudad o del campo. Guido engloba a todos en estas clases de gentes ${ }^{25}$.

Jean Delumeau cataloga la obra de Guido como intermedia entre las sumas y los manuales de confesión: «Deux ouvrages intermédiaires entre "sommes" et "manuels" méritent une mention particulière en raison de l'audience qu'ils recueillirent. Il s'agit du Manipulus curatorum de Guy de Montrocher, curé a Teruel au XIV $\mathrm{XI}^{\mathrm{e}}$ siècle et du Confessionale de l'humaniste néerlandais Godescalc Rosemondt contemporain d'Erasme et de Luther» ${ }^{26}$. En realidad, la obra de Guido no es una suma de penitencia ni un manual de confesión, sino, como proclama el título dado por el propio autor, es un manual de curados, en el que la confesión ocupa un lugar destacado, de acuerdo con el lugar que tenían pecado y confesión en el ámbito de la cura animarum.

22 Incunable Escorial 61-VII-19 n.2, f. 45va: Lo relativo a la sencillez del estilo vale para toda la obra y lo expresa en el proemio-dedicatoria, antes del prólogo, en el folio 1ra-rb: «Hac ergo attenta et uigili meditatione perpensans sequens opusculum de instructione neophitorum curatorum composui, rudi quidem stilo, sed utili, non curans de uerborum ornatu, sed de animarum commodo et profectu».

${ }^{23}$ Incunable Escorial 61-VII-19 n.2, f. 62vb: «Sed ut de peccatis mortalibus possit dari certa regula, notandum quod omnia peccata mortalia ad septem uitia capitalia reducuntur».

24 Ibid., f. 63ra: «Iste igitur sunt septem radices cum ramusculis suis, qui in uniuerso sunt xliii, et sic, computatis septem radicibus, erunt in uniuerso quinquaginta, de quo quinquagenario dixit Elias propheta: Si seruus Dei sum...». (Libro segundo de los Reyes, capítulo priemro, versículo 10).

25 Ibid., f.65rb-va: «Verum quia iuxta uarietatem personarum uariande sunt interrogationes, ideo iuxta uarietatem confitentium debet sacerdos uariare interrogationes. Vnde si confitens sit religiosus...».[Así como conforme a la diversidad de las personas se han de variar las preguntas, del mismo modo el sacerdote debe variar el interrogatorio conforme a la diversidad de los penitentes. De donde, si el confesante es un miembro de una orden religiosa...].

26 Jean Delumeau, Le péché et la peur: La culpabilisation en Occident (XIII ${ }^{e}$-XVIII ${ }^{e}$ siècles), Fayard, París, 1983, p. 224.

Hispania Sacra, LVIII

118, julio-diciembre 2006, 411-447, ISSN: 0018-215-X 


\section{Informatorius simplicium sacerdotum. Anónimo}

El confesional anónimo Informatorius simplicium sacerdotum, también citado antes, parece que se elaboró, a más tardar, durante el siglo XIV, según la datación del catalogador del Ms. escurialense $d$. IV. 2, ff. 33ra-45rb, en el que se contiene $^{27}$. No aparece el nombre del autor, pero se hace promoción de la obra al final del prólogo ${ }^{28}$. Es un manual claro y bien organizado, escrito en latín y para uso exclusivo de los curados. Centra la cura pastoral en el discernimiento de los pecados y entra directamente en el tratamiento del sacramento de la penitencia: saludo de entrada, identificación de quien solicita la confesión y exposición de los pecados con la ayuda del confesor en lo que haga falta, siguiendo un orden a partir de los siete vicios capitales, contenidos en la dicción saligia, y sus concatenaciones, o sea, sus ramos/ramas o hijos/hijas. Coincide en esto con Guido, salvo en que pone un ramo más a la avaricia (la violencia) ${ }^{29}$, con lo que la suma total es de 51 pecados.

Los siete vicios, con sus ramos, ocupan el grueso de la obra (ff. 34va-38vb). Luego expone más brevemente los mandamientos (ff. 38vb-38bisva), los artículos de la fe (ff. 38bisva-39rb), los sacramentos (ff. 39rb-40ra), las obras de misericordia (f. 40ra-rb y los pecados de los cinco sentidos (f. 40rb-vb).

Dedica un capítulo a las preguntas sobre los pecados propios del oficio de cada uno, comenzando por los prelados, al estilo de otros muchos manuales ${ }^{30}$. Se trata de asegurar la integridad de la confesión, en lo que se puede fallar fácilmente por dos razones: primero, porque los hombres suelen ser negligentes a la hora de examinar su conciencia; y segundo, por la ignorancia generalizada de los penitentes ${ }^{31}$. Con el mismo fin se ocupa en sendos capítulos de cómo se debe animar a los vergonzosos y de convencer a los que se resisten; y todavía con este objetivo de asegurar la integridad o quizá, más sutilmente, para que el penitente tenga una nueva ocasión de manifestar su voluntad de hacer una confesión íntegra de sus pecados, inserta una fórmula de confesión general, previa al Confiteor Deo, es decir, al reconocimiento global de la condición pecadora, a la rendición final del penitente como pecador ante Dios y ante los hombres ${ }^{32}$.

27 Guillermo AnTolín, Catálogo... I (Madrid, 1910), 502.

28 F.33va-vb: «Studeant ergo omnes sacerdotes et potissime curam animarum habentes competentem scientiam presentis libelli addiscere, ut videlicet curam animarum tenere et suum officium dignum valeant explere».

29 F. 36vb.

30 El autor expresa la razón del procedimiento seguido, que es la mayor dignidad del estado clerical sobre el laical; y, dentro de cada estado, el orden jerárquico establecido: «Et quoniam a digniori est inchoandum, a prelatis ecclesiarum inquirenda sunt ista...» (cap. 24, ff. 40vb-41 ra).

31 Ibid. f. 40vb.

32 Cap. 27, f. 42va: «In hiis omnibus et in multis aliis peccaui... de quibus omnibus et singulis... dico meam culpam, et peto michi imponi penitentie remedium salutare. Et tunc dicat Confiteor Deo, etc. 
Tras la imposición de la penitencia, la concesión de la absolución y la indicación de los casos reservados, ofrece una recapitulación de todos los pecados, por el siguiente orden: pecados capitales, con sus hijas y especies, mandamientos, artículos de la fe, sacramentos, obras de misericordia, sentidos corporales.

\section{Tratado de confesión de Juan Martínez de Almazán ${ }^{33}$}

A principios del siglo XV, en torno al año $1410^{34}$, Juan Martínez de Almazán, licenciado en artes y bachiller en cánones, escribe una forma de confesión para clérigos y laicos. Con brevedad, buen orden y un estilo preciso y sencillo, recorre las diversas maneras de pecar, deteniéndose un poco en los mandamientos; en las siete raíces de los pecados, siguiendo, según algunos de los manuscritos, el orden de la dicción saligia ${ }^{35}$; y en los cinco sentidos corporales. El vicio capital de la lujuria lo trata en el sexto mandamiento, al que remite también desde el noveno mandamiento. No especifica las ramificaciones de los siete vi-

[Todos estos y muchos otros pecados cometí... de todos los cuales y de cada uno de ellos digo mi culpa y pido se me aplique el remedio saludable de la penitencia. Y entonces diga Confieso a Dios, etc.].

${ }^{33}$ De este breve tratado conozco actualmente seis manuscritos. De ellos, cinco contienen la obra en castellano y uno es un fragmento en latín con el prólogo, ligeramente distinto del que aparece en la versión romance, y el inicio de la obra, lo que pone de manifiesto una primera redacción latina.. Ningún manuscrito contiene la obra al completo. Incluso el manuscrito del fondo español de la Biblioteca Nacional de Francia en París, Esp.432, ff. 151ra-165vb (P), que, a primera vista, parece contener enteramente la obra, está incompleto, pues le falta el apartado relativo a las obras de misericordia corporales; además, tiene algunas diferencias de interés respecto a. los otros manuscritos, que se encuentran en: Biblioteca Capitular y Colombina de Sevilla, dos, ambos en el ms 5-5-27, ff. 81vb-87vb (S) y f. 196va-vb (en este folio se contiene el fragmento latino: S2); Biblioteca Nacional de Madrid, ms 9465, ff. 156v-165v (M); Real Biblioteca de San Lorenzo del Escorial, ms P.III.25, ff. 118r-127v (E); y Biblioteca del Noviciado de la Universidad Central de Madrid, ms 148, ff. 100v-110v (N). En los manuscritos hay variantes de cierta importancia, debido, me parece, a que la obra se difundió bastante, con intereses y por copistas diversos.

34 Corrijo mi primera impresión sobre la fecha de la obra. En mi primer artículo sobre la misma («El "Tratado de confesión” de Juan Martínez de Almazán. Identificación de dos nuevos manuscritos», Revista Española de Teología, 41 [1981], 287-298), me aventuré a situar su fecha de composición entre 1415 y 1435 . Ciertamente, la obra no se escribió después de 1429, puesto que uno de los manuscritos, $\mathbf{N}$, lleva la fecha de 30 de septiembre de 1429. De otra parte, el amanuense parece dar a entender que el autor no estaba ya en activo: «Aquí se acaba vn quaderno de las penitencias que fue sacado de las Decretales, el qual fue sacado de mano de vn licenciado en artes et bachiller en canones que llamauan Juan Martinez de Almaçan» (f. 110v). De otro lado, en octubre de 1403, Juan Martínez de Almazán figura entre los estudiantes de derecho canónico de la Universidad de Salamanca, según Vicente BELTRÁN DE HEREDIA, Bulario de la Universidad de Salamanca (1219-1459), I (Salamanca, 1966), 574, n. 341 (140).

${ }^{35}$ En tres manuscritos, $\mathbf{N}, \mathbf{E}$ y $\mathbf{S}$ se sigue el orden de la dicción saligia, pero sólo en dos, $\mathbf{E}$ y $\mathbf{S}$, se la menciona expresamente; en $\mathbf{M}$ y $\mathbf{P}$, además de no mencionar la dicción, se sigue un orden distinto: soberbia, envidia,ira, acidia, avaricia, gula y lujuria.

Hispania Sacra, LVIII

118, julio-diciembre 2006, 411-447, ISSN: 0018-215-X 
cios; se limita a recoger las principales maneras de pecar en cada uno: tres en la soberbia, dos en la avaricia, dieciséis en la lujuria (son las maneras de pecar contra el sexto mandamiento, al que remite), tres en la ira, seis en la gula, tres en la envidia y dos en la acidia.

Señala aparte doce maneras más de pecar, sin dar razón alguna del por qué. Quizá no vio el modo de distribuirlas entre las diversas listas habituales de pecados, dada la brevedad que se impone al tratar del tema, y, además, las quería destacar especialmente, pues está claro que el hecho de situarlas aparte significa que las considera singularmente importantes ${ }^{36}$.

Dedica también un breve apartado al clérigo que se confiesa ${ }^{37}$. Esta atención particular al clérigo penitente se explica, a mi entender, por la importancia demográfica del clericato, siendo muchos de los clérigos simples beneficiados, sin encomienda de la cura de almas e, incluso, ignorantes de las obligaciones propias de la clericatura.

En cuanto a los artículos de la fe, los sacramentos y las obras de misericordia, se limita a su enunciado, señalando genéricamente cómo se siente el penitente en los artículos de la fe, si cree en los sacramentos y si cumple las obras de misericordia.

No hay graduación de pecados ni consideraciones particulares sobre unos u otros, aparte las matizaciones que se derivan de las circunstancias y de la reserva de ciertos pecados, sea al papa, sea al obispo, lo que pone en conocimiento del confesor para que lo tenga en cuenta a la hora de poner la penitencia y de ver si puede absolver. Lo que destaca en esta obra, fuera de su sobriedad y asepsia en la relación de los pecados, es la importancia que da el autor a la preparación para la confesión, es decir, a la exposición de las condiciones que debe tener la confesión «qual se requiere en la iglesia» ${ }^{38}$.

Por lo demás, la obra debió de tener no poca difusión, aunque probablemente no tanta como su autor deseaba, deseo que expresa en el proemio: «Item encargo las consçiençias de todos aquellos que esta presente forma vieren que la fagan publicar por las eglesias, en tal manera que todos, ansy clerigos commo legos, ayan notiçia de ella» ${ }^{39}$.

36 P, f. 161ra: «Ahun allende de los mandamientos e de las otras cosas que he dicho, digo mi culpa que yo prque en muchas maneras... Lo duodecimo, pensando mucho en las cosas que son del mundo».

37 P, f. 161rb: «O si eres clerigo tu que te confiessas, has de considerar en ti cinco cosas...».

38 En todos los manuscritos se advierte esta importancia, pero especialmente en P (ff.151vb157ra), en el que se recogen las diecisiete condiciones con una exposición más extensa.

39 En P se echa en falta este texto. Utilizo aquí el ms E, f. 118 r. 


\section{Confesión general de André Dias de Escobar}

André Dias de Escobar es un personaje singular por los avatares de su vida $^{40}$; pero, además, es un autor obligado en este tipo de literatura pastoral. Entre sus varias obras dedicadas al tema, escribió dos Confesiones generales, una mayor y otra menor, también conocida en latín como Modus confitendi o Confessio minor o Confessio generalis minor. Por mi parte, para este trabajo me he servido de la Confesión general vertida al romance castellano por Juan de Cárdenas, vecino de Andújar, en 1472, que se conserva en el Ms. 4183, ff. 65r-71r de la Biblioteca Nacional de Madrid, y de un ejemplar incunable, con algunas variantes de diversa consideración, que se conserva asimismo en la Biblioteca Nacional de Madrid, número 1007, con el título: Confession breue y muy vtile. Compuesta por el Reuerendo señor don Andres obispo megarense, penitenciario de la sancta yglesia de Roma. Creo que se trata de otra versión castellana de la misma obra.

André Dias quiere elaborar una forma de confesión, breve y práctica, que sirva de guía al confesor. Su intento tuvo muy buen éxito y fue traducida del latín a varios idiomas, lo que amplió su campo de utilidad. Le cuadra muy bien el título de confesión general, porque es una especie de la oración Yo, pecador, me confieso a Dios... más detallada, con el mismo orden: pecados de pensamiento, palabra, obra y omisión, pero dando más importancia a los pecados de obra por comisión o por omisión, por hacer o por no hacer. De hecho, al tratar de los pecados de obra por comisión, junto a los siete pecados con sus circunstancias, los mandamientos y los cinco sentidos, considera también los de pensamiento y los de palabra; y en los pecados por omisión inserta las obras de misericordia corporales y espirituales, los artículos de la fe, los sacramentos, las virtudes, los dones y frutos del Espíritu Santo y las bienaventuranzas ${ }^{41}$.

El defecto que acompaña al método de la confesión general que propone André Dias es justamente, a mi parecer, la generalización, que lleva a cierta despersonalización de la conciencia del penitente. Siguiendo el método de manera estricta, el fiel se podía confesar de todo y de nada a la vez, si se acusaba de ser pecador en todo. Con la atención puesta en no olvidar ningún pecado, en la integridad de la confesión, el penitente que dispusiera del cuaderno podía limitarse a leerlo entero, o a decirlo, más o menos bien memorizado, en unos minutos. Cierto es que esta despersonalización de que hablo afectaba igualmente a los otros modos de confesión abreviados. Los autores parecen conscientes de

40 Cf. António Domingues de Sousa Costa, Mestre André Dias de Escobar, figura ecuménica do século xv (Estudos e Textos de Idade Média e Renascemento 2, Roma-Porto, 1967).

41 Por cierto, en la versión manuscrita se habla de siete bienaventuranzas, aunque en su breve explanación se exponen las ocho, incluyendo la octava en la séptima (f. 70v): «Setimo, pacifico no fuy ni por Ihesu Christo persecuçiones ni maldiçiones sofri».

Hispania Sacra, LVIII

118, julio-diciembre 2006, 411-447, ISSN: 0018-215-X 
este peligro y lo consiguen obviar mediante el interrogatorio del confesor al penitente, interrogatorio que será discreto y adaptado a la condición del penitente, o sea, un interrogatorio personalizado.

La dicción saligia aparece en el incunable, no en la exposición primera de los pecados, sino en una breve recapitulación final que no figura en el manuscrito. En el orden de tratamiento de los siete pecados mortales figura en cuarto lugar la envidia (invidia) y en sexto la ira, tanto en el manuscrito como en el incunable; lo cual en nada obsta a la dicción saligia, dado que estas dos palabras son intercambiables, al empezar ambas con la letra $\mathbf{i}^{42}$.

La obra acaba con un aviso al confesante: que se recoja en si mismo y se esfuerce por recordar sus pecados, aviso que también figura de forma parecida en la recapitulación citada del incunable ${ }^{43}$, lo cual es una prueba más de la primacía del pecado y de su dicción oral. Decirlos da ocasión a ser perdonado; ocultar alguno significa no ser perdonado y cometer uno nuevo, de manera que quien actúe así deberá repetir la confesión íntegramente.

La relación de pecados es simple, sin énfasis especial en alguno de ellos, fuera de la cautela que debe observar el confesor al preguntar sobre los pecados de lujuria, con el fin de no dar ocasión a posibles nuevos pecados ${ }^{44}$.

\section{Sacramental de Clemente Sánchez de Vercial}

Clemente Sánchez, autor de varias obras de contenido religioso ${ }^{45}$, empezó a escribir esta obra en Sigüenza en el mes de agosto de 1421 y la acabó en la ciudad de León a finales de marzo de 1423, siendo arcediano de Valderas, en la diócesis de León, según afirma en el proemio ${ }^{46}$. El Sacramental se asemeja al

42 Incunable BNM 1007, f. 11v: «Los siete pecados mortales antedichos se entienden por esta dicción saligia, entendiendo por cada letra su pecado».

43 Ms BNM 4183, f. 71r: «Avisote, o confesante... que te recolijas en ti mesmo y te esfuerces de te recordar si en algunt tiempo algunt pecado en especial semejante...»; Incunable BNM 1007, f. 13v: «Avisote, o penitente, que reduzgas... y mira que te recuerdes si feziste en algun tiempo especial algun pecado semejable».

44 Incunable BNM 1007, f. 5r.

45 Cf. Horacio Santiago-OTERo, «El Sacramental de Clemente Sánchez de Valderas», Monumenta Iuris Canonici, Series C: Subsidia, vol. 7 (Biblioteca Apostolica Vaticana, Città del Vaticano, 1985), 153161; Antonio García Y GARcía, «Nuevas obras de Clemente Sánchez, arcediano de Valderas» y «En torno a las obras de Clemente Sánchez, arcediano de Valderas», Iglesia, Sociedad y Derecho (Universidad Pontificia, Salamanca, 1985), 143-162 y 163-167. José BARBOSA MACHADO, Profesor de la Universidad de Trâs-Os-Montes e Alto Douro, ha realizado recientemente una edición semidiplomática de la versión portuguesa del Sacramental, enriquecida con un estudio histórico-cultural e informático-lingüístico.

46 El proemio ocupa el folio Ixr-v. Utilizo un ejemplar incunable de la Real Biblioteca del Escorial, signatura 75-VI-15, impreso en Sevilla por los maestros Antón Martínez, Bartolomé Segura y Alfonso del Puerto un jueves, 28 de mayo de 1478, según se hace constar al final, en f. 183v. 
Manipulus curatorum de Guido de Monte Roterio. Al igual que éste, no es propiamente un manual de confesión, sino una instrucción de la doctrina cristiana y bastante completa, por cierto, aun cuando el autor la califique de breve, para uso de los clérigos curados. Clemente afirma que su propósito es fazer vna breue copilacion de las cosas que necessarias son a los sacerdotes que an cura de animas ${ }^{47}$.

Los sacramentos constituyen el tema estrella sobre el que versa la obra; y por eso le pone el nombre de Sacramental. En efecto, los sacramentos ocupan dos de los tres libros, en que se divide la obra; que, a su vez, contienen 381 de los 447 títulos, que en folios se traducen en 134 de un total de 183, o sea, el $73,22 \%$. Y el primer lugar lo ocupa la penitencia, con 118 títulos y 53 folios.

Del pecado trata directamente en el libro primero, a continuación de los mandamientos, que es lo habitual en este tipo de tratados, en 20 títulos, la mitad de los cuales se refieren a los siete pecados mortales según la dicción saligia. Vuelve a ocuparse del pecado, como es lógico, y de los siete mortales principalmente, al tratar del sacramento de la penitencia. Con lo cual se confirma que el pecado y su perdón constituyen el eje de la actividad pastoral del sacerdote que tiene encomienda de cura de almas.

El Sacramental gozó de una muy buena acogida durante largo tiempo, a juzgar por su gran difusión. Es cierto que se conocen hasta ahora pocos manuscritos $^{48}$; pero, habida cuenta de su tradición editorial, con al menos 14 ediciones incunables, se puede afirmar, sin miedo a equivocarnos, que su difusión manuscrita fue también excelente. En 1559 fue incluido en el Índice de libros prohibidos del Inquisidor General Fernando Valdés y luego ya en Índices posteriores de España y Portugal, probablemente por su forma de abordar la problemática planteada en el campo de la moral práctica y por algunas inexactitudes, más verbales que de fondo, que se advierten en la exposición de la doctrina ${ }^{49}$.

\section{Speculum peccatoris, confessoris et praedicatoris. Anónimo}

Esta obra, de autor español desconocido y aún inédita, que se conserva en el manuscrito 37 de la Biblioteca de la Real Colegiata de San Isidoro de León ${ }^{50}$,

\footnotetext{
47 Incunable 75-VI-15, f. IXr.

48 Sólo tres: Biblioteca Nacional de Madrid, ms 56, ff. 1r-226r; y ms 9370, ff. 1ra-136va; Real Biblioteca de San Lorenzo del Escorial, ms. J.II.20, ff. 1r-306r.

49 Cf. José María Soto RÁbanos, «El Sacramental de Clemente Sánchez», en el Índice de libros prohibidos, Os Reinos Ibéricos na Idade Média. Livro de Homenagem ao Professor Doutor Humberto Carlos Baquero Moreno (Livraria Civilização, Porto, 2003), 709-719.

50 Cf. J. Pérez Llamazares, Catálogo de los Códices y documentos de la Real Colegiata de San Isidoro de León (León, 1923), p. 50, n. ${ }^{\circ} 37$.
} 
fue escrita después de 1431 y muy probablemente antes de $1435^{51}$. Es, y así lo quiere el propio autor, un manual amplio de confesión destinado a los rectores de almas. El punto de partida es que todo pecado implica una deuda que es necesario satisfacer, según la conocida proposición moral formulada por san Agustín de que no hay perdón sin restitución ${ }^{52}$.

Si tenemos en cuenta, de una parte, la erudición de que hace gala el autor y su recurso constante a autoridades doctrinales, jurídicas y teológicas, y, de otra, el punto de arranque, que condiciona el desarrollo teórico-práctico de la obra, bien cabría afirmar que se trata de un tratado erudito sobre la obligación de restituir.

En este caso, lo traigo a colación en su calidad de tratado de confesión, que lo es también plenamente, no sólo en la intención del autor sino asimismo en su elaboración. Examinado en esta faceta, nos encontramos con un texto sobre la base de pecadores-deudores diversos, catalogados conforme a su estado social, sea en el ámbito de la Iglesia sea en el de la sociedad civil. Se asemeja a la segunda parte del Libro de las confesiones de Martín Pérez, obra que nuestro autor muestra conocer y de la que se hace eco, al igual que del Manipulus curatorum de Guido de Monte Roterio, poniendo de relieve la gran difusión de ambas obras $^{53}$.

\section{Libro de confesión de Medina de Pomar}

Esta obra anónima ha sido editada y estudiada por Hugo O. Bizarri y Carlos N. Sainz de la Maza en tiempos recientes ${ }^{54}$. De los datos aportados se deduce que la obra es con toda seguridad anterior a $1455^{55}$.

Desafortunadamente, el texto está incompleto. Falta el principio, folios 1 y 2 , en el que podemos suponer que el autor o compilador ofrecería algunos datos sobre la obra, su finalidad, destinatarios de la misma, etc. La falta de texto inicial afecta también a parte del primer mandamiento. Faltan, además, los folios

51 Cf. José María Soto RÀbanos, «Derecho canónico y praxis pastoral en la España bajomedieval», Monumenta Iuris Canonici, Series C: Subsidia, vol. 7 (Biblioteca apostolica Vaticana, Città del Vaticano, 1985), p. 601, nt. 19.

52 Ep. ad Macedonium, PL 33, 662: «Si enim res aliena, propter quam peccatum est, cum reddi possit, non redditur, non agitur poenitentia sed fingitur: si autem veraciter agitur, non remittetur peccatum, nisi restituatur ablatum; sed, ut dixi, cum restitui potest».

53 Ms. 37, f. VIv.

54 Edición y una breve introducción: «El Libro de confesión de Medina de Pomar», Dicenda. Cuadernos de Filología Hispánica, 11 (1993); 35-55, 12 (1994); 19-36, 13 (1995); 25-37. Descripción y estudio codicológico: «Un confesional castellano en sus dos fuentes manuscritas», Incipit, 7 (1987), 153-160.

55 O.c., 11 (1993), 37-38. 
6 y 7, con las consideraciones finales sobre el cuarto mandamiento, todo el quinto y el principio del sexto.

No me detengo en el examen de la obra, remitiendo al estudio citado; simplemente, quiero destacar algunos detalles. Consta de dos partes bien definidas; la primera (28 folios) es, propiamente, el libro de confesión; la segunda se puede considerar un libro de ejemplos, puesto que contiene reflexiones y consejos sobre la confesión y acopio de sentencias de la Escritura y de los Santos Padres, con 38 ejemplos para los alegatos de autoridades.

Para el objetivo que me propongo en este trabajo interesa la primera parte de la obra, como resulta lógico. Nos presenta una práctica de la confesión centrada en los diez mandamientos y en los siete pecados mortales. Aunque hace referencia a otras partes de la doctrina cristiana desde la perspectiva del pecado, se detiene muy poco en ellas. Del folio $3 \mathrm{r}$ al $12 \mathrm{v}$ (el 32,7 \%) trata de los mandamientos. A los siete pecados mortales dedica un poco más, del folio $12 \mathrm{v}$ al $22 \mathrm{r}$ (el 35,7\%). No los define ni comenta, va directamente a los ramos de cada pecado. No se atiene a la dicción saligia y sigue un orden caprichoso: soberbia, envidia, ira, acidia, avaricia, gula y lujuria. En cuanto a la lujuria, que coloca en séptimo lugar, remite a lo expuesto en el sexto mandamiento ${ }^{56}$. Inserta referencias brevísimas a los cinco sentidos (ff. 22v-23v), a las siete virtudes (ff. 23v$25 \mathrm{v}$ ), a las obras de misericordia corporales y espirituales (ff. 25v-26r), a las bienaventuranzas (f. 26r), a los pecados de la lengua (f. 26v), a los sacramentos (ff. 26v-27r), al tiempo perdido (f.27r) y al no cumplimiento de las penitencias de maestros y confesores (ff. 27r-v). Finaliza esta primera parte con una forma breve de confesión general, a modo de recapitulación de los pecados, y petición de perdón y penitencia por parte del confesado (ff. $27 \mathrm{v}-28 \mathrm{v})$.

\section{Tratado sobre las confesiones de Alfonso Fernández de Madrigal}

Alfonso Fernández de Madrigal (ca. 1410 - 1455), conocido con los sobrenombres de «el Tostado» y «el Abulense», entre las muchas obras que escribió en su corta vida, figura una breve forma de confesión. Escritor de muy diversas materias religiosas, se manifiesta más como teólogo que como canonista. Para este trabajo he utilizado el ejemplar manuscrito 4202, ff. 103ra-131rb, de la Biblioteca Nacional de Madrid ${ }^{57}$.

56 O.c., 11 (1993), 51 [f. 22r]: «El séptimo pecado es luxuria. Digo a Dios mi culpa e a vos. E d'este pecado asaz es dicho en el sexto mandamiento». El espacio dedicado al sexto mandamiento se suma asimismo al que he anotado para los pecados mortales, con lo que este porcentaje se hace aún mayor.

57 Este manuscrito lo hizo Alfonso Aguado, clérigo de San Adrián en el estudio de Salamanca y lo acabó el lunes, 10 de marzo de 1460, según se indica en el colofón del mismo, f. 131rb. He consultado 
El Tostado empieza a estilo teológico clásico, señalando los dos remedios que Dios ha dado al hombre, conforme a los dos pecados-tipo: el bautismo para el pecado original, y el sacramento de la penitencia, segunda tabla de salvación, para el pecado actual; y que es la ignorancia de muchos en esta materia la razón que justifica la escritura de la obra ${ }^{58}$.

Después de las primeras instrucciones y consejos, llega al propósito del tratado: los pecados capitales. No los expone por el orden de la dicción saligia, sino por este otro: soberbia, lujuria, gula, envidia, ira, pereza (acidia) y avaricia. Considera la avaricia el último de los siete pecados mortales, no por su importancia sino en el orden clasificatorio, y es el pecado en el que se extiende más, a lo largo de nueve folios, algo más que en todos los demás juntos, a causa de dos de sus ramas: la usura y la simonía ${ }^{59}$.

La exposición del contenido de la doctrina cristiana no tiene como fin directo la enseñanza de la doctrina, sino el señalar los pecados que se cometen en contra; y desde ese prisma expone el Tostado la doctrina: los mandamientos, los sentidos corporales y las obras de misericordia. Curiosamente, no expone los artículos de la fe ni las virtudes, las siete: tres teologales y cuatro cardinales. Me parece claro que la razón de esta omisión es que estos dos conceptos son positivos, responden a la fe y al poder de la fe, quiero decir, al hecho de creer determinadas proposiciones y al poder, o virtud, que se deriva de ese hecho de creer. No se trata de conceptos negativos, no se trata de conceptos de enfrentamiento, sino de ejercicio de la vida cristiana. Es cierto que también cabe integrarlos en los modos o manuales de confesión, interesándolos en sentido inverso, como lo hacen otros autores; es decir, en la posible vertiente de no respuesta. Parece que El Tostado observa aquí el pecado desde la perspectiva de lo meramente negativo, de la prohibición y el incumplimiento de lo mandado; no desde la simple debilidad de la fe y de la virtud.

asimismo otro manuscrito, que se conserva también en la Biblioteca Nacional, núm. 4183, ff. 1r-64v, escrito por Bartolomé de Alcaraz en Andújar (Jaén), por mandato de su señor Pedro de Escrivias, guarda mayor del rey, y lo acabó el jueves, 13 de agosto de 1472, según consta igualmente en el colofón del mismo. Este manuscrito contiene la obra con diversas variantes sin mayor importancia, pero está falto de varios folios al principio. Por cierto, en Andújar y el mismo año 1472, el amanuense Juan de Cárdenas copió la Confesión general de André Dias de Escobar, que se conserva en el ms 4183, ff. 65r-71r de la Biblioteca Nacional de Madrid, como he señalado anteriormente.

58 «[original]... para el que Dios nos dio el remedio del baptismo para el que non auemos mester confession nin arrepentimiento», [y pecados actuales] «que nosotros facemos e estos non se han de tirar por el baptismo... mas ha de mester otro remedio por lo qual el sacramento de la penitencia fue ordenado... et porque muchos por ignorancia, non se sabiendo confessar, yerran en este sacramento, en breue la forma de confessar con algunas avisaciones para esto trataremos (f.103rb).

59 Ms. 4202 BNMadrid, ff. 113ra-121rb. A los otros pecados les dedica los folios 105vb-113ra, destacando la lujuria con cerca de 4 folios (106vb-110ra). 


\section{Libro de confesión de Bartolomé Talayero}

Esta obra se conserva inédita en el Ms 10571, ff. 1v-95r, de la Biblioteca Nacional de Madrid. Fue escrita por Bartolomé Talayero en 1474 por encargo del entonces Justicia de Aragón, Ferrer de Lanuza y a instancia de personas nobles y devotas ${ }^{60}$. Escrita en romance aragonés, va dirigida directamente a los penitentes, sin mencionar su posible utilidad para los confesores, dando por sentado que los confesores conocen suficientemente el oficio; no obstante, no faltan algunos consejos para ellos. Es, de principio a fin, un tratado de confesión, no una instrucción de la doctrina cristiana que contenga un modo de confesión. El autor afirma que escribe en estilo llano, de modo que pueda aprovechar a personas de cualquier estado y, por ello, huye de citas eruditas, que quedan al alcance de los letrados ${ }^{61}$.

Divide la obra en dos partes principales: proemio y tratado ${ }^{62}$. En el proemio, llamado así por el propio autor debido sin duda a su carácter introductorio dentro del conjunto del libro, responde a una serie de seis interrogantes acerca de otros tantos aspectos conceptuales: penitencia, contrición, confesión, satisfacción, remisión, absolución. Esta parte ocupa 26 folios (del 3v al 29v), o sea, un tercio del total de la obra. La otra parte principal, el tratado, es de carácter práctico y ocupa los dos tercios restantes (del 29v al 95r). Los primeros folios ( $1 \mathrm{v}-$ $3 v)$ son de presentación del escrito.

En la práctica de la confesión contempla ocho apartados, por orden de los cuales cada uno deberá confesarse: los diez mandamientos, los siete pecados mortales, los cinco sentidos corporales, las siete obras de misericordia espirituales, las siete obras de misericordia corporales, las tres virtudes teologales, las cuatro virtudes cardinales y los sacramentos ${ }^{63}$. Afirma que se debe empezar por los diez mandamientos ${ }^{64}$, pero presta una atención más extensa y particularizada a los siete pecados capitales, reconociendo que todos los pecados se reducen a los siete capitales ${ }^{65}$.

60 Ms 10571 BNMadrid, f. 1v: «Aquesta confession fu compilada el anyo de la Natiuidat de Nuestro Señor de mil quatrocientos setanta quatro a instancia e mandado del muy magnifico senyor mossen Ferrer de la Nuça, Justicia de Aragon»; f. 2v: «... por ende a instancia de algunas muy nobles e deuotas personas es stada compilada la presente confession».

61 Ibid., ff. 2v-3r: «No es la uoluntat por ahora del scriuiente allegar libros nin capitolos, stimando que los letrados que la lieren no amenguan de aquellos e seria turbar a los simplices por cuyo respecto primeramente se haze».

62 Ibid., f. 3r-v: «De donde razonablemente podemos tomar la diuision de la presente suma siquier confession, ca es partida en dos partes, es a saber, en proemio e tratado... Cada una dellas sera en su lugar subdiuidida».

63 Ibid., f. 30r: «Qualquier que se confesare bien destas ocho partes restara confesado acabadamente».

64 Ibid., f. 34r-v: «Para el buen orden debemos proceyr por los diez mandamientos».

65 Ibid., f. 44r: «hay siete especies principales, a las que se reducen todas las maneras de pecar; y f. 91v: «maguer que muy muchos fueren los pecados mortales... todos son reducidos a los siete pecados capitales». 
Bartolomé Talayero no ignora que en la confesión se ha de atender al estado y condición de cada cual, tanto por parte del penitente en la dicción de los pecados como por parte del confesor en el interrogatorio, como forma adecuada para aquilatar las circunstancias de los pecados, pero no entra en más detalles, no se detiene a especificar qué pecados suelen cometer unas u otras personas según su estado. Se conforma con advertir que, a la vista de la exposición de pecados, cada penitente tendrá en cuenta los que le afectan más por su situación personal y social ${ }^{66}$.

Una característica a destacar en Bartolomé Talayero es que muestra un interés superior al de otros autores del género en dar pautas para el buen discernimiento entre los pecados mortales y los veniales. Considera esta faceta especialmente útil ${ }^{67}$.

\section{Tratado de confissom de Chaves (1489)}

Esta obra ha sido editada cuidadosamente y estudiada minuciosamente en sus aspectos históricos y filológicos en fechas recientes por el Profesor José Barbosa Machado; y a su estudio remito para una información más amplia, si bien no puedo menos de exponer una serie de breves anotaciones ${ }^{68}$.

Se trata, sin duda, de una obra singular; se asemeja a muchas, pero se diferencia de todas. De ahí, quizá, la dificultad de encontrar para ella un origen cierto. Parece una selección de textos, tomados quizá de obras latinas o castellanas, llevada a cabo en el entorno de Chaves con el buen deseo de llenar algún vacío, pero conjuntada sin mucho acierto, dadas sus repeticiones e irregularidades. No es, a mi juicio, una obra de autor. Es, por otra parte, válida tanto para confesores como para penitentes; y se advierte en sus páginas cierto olor a claustro, con lo cual no quiero decir que fuera escrita pensando sólo en la confesión de clérigos y religiosos, sino que parece elaborada en un ambiente de vida en comunidad, de cabildo o convento, aunque con utilidad para cualesquiera confesores y penitentes.

El autor no organiza bien la obra, pero cabe distinguir tres partes. En la pri-

66 Ibid., f.3r: «... a assi, allegandonos al proposito, quantoquier muchas otras cosas se houiesen e podiesen dezir acerca de la presente suma, solo deliberamos, antes de entrar en el proceso y orden que entendemos ensenyar, como cada qual, según su stado y condicion, se haya de confessar e satisfazer a las preguntas que por los dichos confessores en general nos porran ser dichas».

67 Ibid., ff. 91v-92r: «... ca es de mucha utilidat por nos ensenyar quales son los pecados mortales y quales los veniales, con algunas otras pequenyas determinaciones»; y en ff. $94 \mathrm{v}-95 \mathrm{r}$ : «E como quier que otras muchas maneras houiere de pecados veniales, stos empero son en los que mas comunmente entropeçamos, por donde es bien de los hauer dicho».

68 Tratado de Confissom. Edição semidiplomática, estudo histórico e informático-lingüístico de José Barbosa Machado (Ed. APPACDM, Braga, 2003). 
mera expone el modo práctico de confesarse. Tras el prólogo, la acogida y primeras preguntas al penitente, el confesor le dejará confesarse, salvo si advierte que no sabe, pues en ese caso le dirigirá las preguntas de rigor en el orden siguiente:

a) los pcados mortales, sin seguir en este caso el orden de la dicción saligia, sino este otro: soberbia, envidia, ira acidia, avaricia, lujuria, gula;

b) los cinco sentidos. En realidad, no es este su sitio, de modo que los anuncia en segundo lugar, pero los expone después de los mandamientos y de otras preguntas para penitentes clérigos y religiosos;

c) los diez mandamientos, que los anuncia en tercer lugar, pero los expone en segundo, después de los pecados mortales.

Sigue una confesión general, al estilo de la conocida fórmula: Yo, pecador, me confieso a Dios, con nuevo recorrido por los pecados mortales, los cometidos a través de los cinco sentidos y contra los mandamientos, añadiendo ahora los cometidos contra los sacramentos.

En la segunda parte expone la penitencia a imponer por algunos pecados, al estilo de la penitencia tarifaria de los libros penitenciales. Se inspira de modo especial en el Decreto de Graciano. Relativamente, en atención al conjunto del tratado, se detiene por extenso en el pecado de lujuria, único de los pecados mortales que aquí contempla; es breve en el de homicidio y en el de juramento; y es muy breve, e incompleto, en los pecados contra los sacramentos.

La tercera parte es una instrucción breve de la doctrina cristiana. Contiene los artículos de la fe, los pecados mortales, siguiendo en esta ocasión la dicción saligia (soberbia, avaricia, lujuria, ira, gula, invidia, acidia) y siendo, de nuevo, la lujuria el pecado tratado con más amplitud.

Pero el interés mayor de esta parte para el tema del pecado y la confesión del mismo está en que, sin dar explicación alguna de por qué lo hace aquí, el autor inserta un capítulo sobre pecados principales conforme al estado y profesión de algunos penitentes; en concreto de: religiosos, príncipes, jueces, caballeros, mercaderes, menestrales, oficiales de señores y labradores. La inserción de por si en el Tratado de confissom de Chaves no tiene por qué sorprender, es normal; pero sorprende el modo y el lugar de la inserción. Sorprende porque lo normal, por lógico, hubiera sido insertar esta cuestión en la primera parte, en la que trata del modo práctico de confesarse. Incluso, no hubiera extrañado en demasía si la hubiera situado en la segunda parte, en la penitencia a imponer por algunos pecados, pero en ningún caso se puede aceptar como su lugar propio la instrucción de la doctrina cristiana.

También llama la atención el hecho de que en el tratado aparezcan tres lista- 
dos de los siete pecados mortales, que, en realidad, se pueden reducir a dos, dado que entre la primera y la segunda lista hay una diferencia meramente nominal: en la primera lista utiliza el término gargantería y en la segunda usa el de gula, manteniendo el mismo orden. En el tercer listado cambia el orden y sigue la dicción saligia. De otra parte, en la confesión general, que da fin a la primera parte, se mencionan cinco de los siete pecados; no aparecen ni la lujuria, de la que trata con cierta extensión en las partes segunda y tercera, ni la ira.

\section{Tractatus de confessione peragenda de Sebastián Ota}

Se trata de una forma breve de confesión escrita en latín y dirigida a los confesores. El autor afirma que la escribe por encomienda del obispo de Plasencia Gutierre de Toledo (1496-1506), a quien se la dedica ${ }^{69}$. Se conserva en edición incunable, hecha en Salamanca en 1497. He podido consultar un ejemplar existente en la Biblioteca de la Catedral de Sevilla. De los datos indicados se deduce que esta obra fue escrita con posterioridad al 27 de junio de 1496, fecha de la promoción de Gutierre de Toledo, y no después sino a lo largo del año 1497, fecha del incunable.

Hay aspectos de la configuración de la obra en los que Sebastián Ota sigue la pauta de Bartolomé Talayero en el Libro de confesión. Uno y otro buscan ser prácticos. Cierto es que en esta clase de escritos, en todos ellos, hay una carga fuerte de practicidad, pero en algunos casos, como en estos dos autores, esa carga es buscada especialmente; de ahí que sean parcos en los temas teóricos y que, dentro de la mayor o menor extensión de cada uno, se detengan más en el ejercicio mismo de la confesión. En el caso de Sebastián Ota, a esa brevedad teórica le ayuda asimismo el hecho de dirigirse a los confesores y no a los penitentes; da por supuesto que los penitentes no toman parte activa en la dicción de los pecados, que se conforman con responder al interrogatorio del confesor, punto en el que se aleja de la opinión de Talayero, quien considera un grave error la confesión a base de las preguntas del confesor ${ }^{70}$.

De otro lado, también Ota se preocupa de acompañar la relación de los pecados con la calificación de gravedad o levedad que le merece cada uno. En su afán de concretar, nos viene a decir que los pecados o vicios capitales o morta-

69 Incunable Sevilla, f. 2r-v: «Vere illustri ac reuerendissimo domino Guterrio a Toleto, Placentino presuli dignissimo frater Sebastianus de Ota, ordinis praedicatorum, ad manuum oscula paternalium... Accipiat ergo vestra magnifica atque reuerendissima dominatio exiguum munus, immo obedientie aliquale seruicium». Para el incunable, cf. Francisco VINDEL, El arte tipográfico en España durante el siglo XV, 2 (Madrid, 1946), 133-134; 8 (Madrid, 1951), 160.

70 Ms 10571 BNMadrid, f. 2v: «...arbitrantes quel padre confesor los ha de interrogar adeuinando sus pecados, lo qual es gran yerro y no mucho seguro a la conciencia del penidiente». 
les no son siempre graves, lo que sería como decir que los mortales no son siempre mortales; pero esto es una apariencia. La verdad es que aquí se atiende a dos perspectivas: al concepto de vicio o pecado capital o mortal como raíz de pecados y a la acción pecaminosa concreta, que será más o menos grave según las circunstancias. Pongamos un ejemplo del propio Ota, en el que explica cómo la ira, que es en todo caso un pecado o vicio mortal o capital, puede ser grave, leve o, incluso, no ser pecado: «Si tuvo odio contra alguien y por el tiempo que duró, el pecado será mortal si le deseó el mal sin más, separándole de su oración; será venial, si deseó darle algún castigo mediano por sus maldades; y no será pecado, si le deseó castigar llevado por el celo de la justicia» ${ }^{71}$.

La obra consta de un proemio, denominado por Ota epistola prohemialis, en el que ofrece algunos datos sobre la obra: dedicatoria, finalidad, planificación, y de cuatro capítulos. El primer capítulo, de apenas un folio (2v-3v), lo dedica a la parte teórica fundamental ${ }^{72}$; el segundo a la práctica de la confesión y orden de interrogar, léase confesar ${ }^{73}$; el tercero al interrogatorio conforme al estado y oficio de cada penitente ${ }^{74}$. El capítulo cuarto, que da fin a la obra, contiene cuatro fórmulas de absolución: la común, la de excomunión, la plenaria y la de dispensa de irregularidades ${ }^{75}$.

La confesión propiamente dicha se centra en los capítulos segundo y tercero. Se trata, en realidad, de un interrogatorio con doble vertiente: una común a todos y otra circunstanciada a cada penitente.

En primer lugar, el interrogatorio camina por los diez mandamientos y por los siete pecados mortales, que se memorizan en la dicción saligia. Ahora bien, dado que los seis últimos mandamientos están contenidos en los siete pecados mortales, bastará confesarse, o que el confesor interrogue, por los cuatro primeros mandamientos y pasar enseguida a los pecados mortales ${ }^{76}$. Además, tiene en cuenta las obras de misericordia corporales y espirituales. Las menciona por dos veces: primero, de modo específico, una por una, con los versículos mnemotécnicos de cada clase, dentro del pecado de avaricia; y luego, de modo genérico, dentro del de acidia ${ }^{77}$.

71 Ibid., f. 6v: «Si odium habuit contra aliquem et quantum durauit: mortale, si omnino ei desiderat malum, separans eum ab oratione sua; veniale, si castigari eum desiderat propter mala sua mediocriter ex vindicta; nullum, si ex zelo justicie».

72 Ibid., f. $2 \mathrm{v}$ : «... et primo quinque preambula documenta ponuntur».

73 Ibid., f. 3v: «Capitulum secundum. De practiva confessionis et ordine interrogandi».

74 Ibid., f. 8r: «Capitulum tertium de diuersis officiis et statibus interrogationes».

75 Ibid., f.11r-v. Ota considera esta parte como «capitulum quartum» de su obra, pero sólo es un añadido, que se suele hallar en muchos escritos de este tipo.

76 Ibid., f. 3v: «Practica autem confessionis per decem precepta fit, et per septem peccata mortalia. Veruntamen, quia sex ultima precepta plene continentur in septem peccatis mortalibus, satis est de quattuor primis confiteri, et statim transire ad peccata mortalia».

77 Ibid., ff. $5 \mathrm{v}$ y $7 \mathrm{v}$, respectivamente. 
Para Sebastián Ota en este punto se puede dar por cumplida la confesión. Es consciente de que muchos autores la prolongan, preguntando sobre otros temas, como de las virtudes, de los dones del Espíritu Santo y de los cinco sentidos, pero él opina que es mejor, y que basta, hacer la confesión según lo indicado, porque el exceso de palabrería difumina la gracia de la compunción y del dolor $^{78}$.

Ello no obsta para que a ese interrogatorio general, por los cuatro primeros mandamientos y los siete pecados, se añada un segundo interrogatorio, circunstanciado al estado y profesión, u oficio, del penitente ${ }^{79}$. A manera de ejemplo, Ota hace referencia expresa a los siguientes: clérigos, entre los que destaca a los obispos, a los curados y a los beneficiados simples; jueces eclesiásticos; príncipes; jueces seculares; abogados; jurisperitos; notarios; maestros; mercaderes; artesanos; y padres de familia. Sin entrar en detalles, señala aquellos pecados que afectan más a cada uno de ellos con relación a sus deberes específicos ${ }^{80}$.

No se trata, en la práctica, de hacer estos dos interrogatorios separadamente, uno después del otro, sino de integrar el especial en el general, seleccionando en éste lo que afecte al penitente en cuestión, ya que entre los cuatro primeros mandamientos y los siete pecados capitales se contienen todas las maneras de pecar.

\section{AlgunAS CUESTIONES EN TORNO A LOS PECADOS}

\section{Noción de pecado}

El pecado dice relación a Dios, es una ofensa a Dios, aunque la acción vaya directamente contra el prójimo y aunque se hable de pecados contra Dios, contra el prójimo y contra uno mismo, y aunque se diga, como Alfonso Fernández de Madrigal, que todo lo que se hace contra la ley o la razón es pecado ${ }^{81}$, lo es

78 Ibid., f. 7v: «Aliqui autem prolongant confessionem inquirentes aduc de multis aliis, puta de tribus uirtutibus theologicis... Sed melius et magis sufficienter videtur fieri confessio sicut dictum est, quamuis vnusquisque mediocriter doctus sue deuotioni possit relinqui, si non sit nimius excessus, qui verborum multitudine graciam compunctionis et doloris euacuat».

79 Algunos autores no incluyen este interrogatorio particular. Juan Martínez de Almazán sólo se ocupa, y muy brevemente, de los pecados propios del clérigo. En las versiones castellanas de la Confesión general de André Dias de Escobar y en los tratados de Alfonso de Madrigal y de Bartolomé Talayero no se incluye. La ausencia de este interrogatorio se puede compensar con el primer interrogatorio del confesor, al inicio de la confesión, sobre la identidad del penitente y al indagar sobre las circunstancias del acto pecaminoso.

80 Ibid., f. 8r: «In speciali de singulis statibus ponendus est nunc ordo confessionis, et primo de ecclesiasticis, scilicet, episcopo, curato et simplici beneficiato».

81 Ms BNMadrid 4202, f. 108va. 
sólo por Dios. El mismo autor afirma que el pecado se somete a confesión como ofensa a Dios ${ }^{82}$. Las demás consideraciones son circunstancias que pueden afectar a la cualificación de esa ofensa a Dios. El pecado, como la buena acción, se dice tal por relación a Dios. Sin Dios no hay buena acción ni hay pecado. Vemos, no obstante, que los actos humanos son contemplados, en su perspectiva moral de buenos o malos, las más de las veces, desde un punto de vista social; es decir, que existen y se exige su puesta en práctica o su omisión en tanto en cuanto hay una convivencia. Así que en los tratados de confesión el acto humano en su vertiente ética dice, ante todo, relación al hombre, a la convivencia, a la sociedad; y responde a una imposición externa, desde fuera, que se satisface negativa o positivamente. A este aspecto del acto humano atiende el interrogatorio al penitente según su estado y oficio: si ha cumplido con sus obligaciones profesionales. Al mismo tiempo, empero, el acto humano es moralmente malo, es pecado, y lo es en mayor o menor grado, solamente en cuanto ofende a Dios.

El pecado no se tiene en cuenta como tal en principio con relación a la desobediencia de la normativa humana, porque a quien hay que obedecer es a Dios, no a los hombres. De ahí que las constituciones conciliares y sinodales puras, en cuanto son lo que son, preceptos humanos, aunque se deba suponer que no contradicen al evangelio ni a la ley divina ni al derecho natural, no suelen obligar bajo pecado mortal, no coartan la conciencia hasta ese punto y su obligatoriedad empieza y acaba en el mandato sinodal: obligación jurídica simple, salvo que de una manera entendible se exprese la obligación sub gravi. No hay contradicción en ello, la cuestión es clara: la ley moral y la razón son cosa de Dios ${ }^{83}$.

\section{La ignorancia protege del pecado}

La conciencia individual juega un papel importante. Con mayor o menor insistencia, todos los autores suelen indicar que cada penitente se confiese, si lo sabe hacer, o responda al interrogatorio del confesor, en su caso, según el dictado de su conciencia ${ }^{84}$.

82 Ibid., f. 103rb-va: «el pecador el qual con sus malas obras ofendió a Dios...».

83 La juridización de la Iglesia durante este periodo bajomedieval no se llevó a cabo sin oposición. Todavía en el siglo XV, el autor del Speculum peccatoris, confessoris et praedicatoris clama contra los ilusos teócratas de su tiempo que seguían creyendo que la Iglesia y la sociedad en general se podían regir por la sola teología, sin el derecho: «Et est hoc contra aliquos presumptuosos qui anichilant et vituperant iura canonica et civilia, quasi sint modici valoris, dicentes quod per solam theologiam posset mundus regi» (Ms 37 León, f. 26r). Cf. Sobre esta cuestión mi artículo: «Los saberes filosófico-teológicos frente a los saberes jurídico-canónicos en algunos autores españoles medievales», Veritas, 43/3 (1998) 525-539.

${ }^{84}$ Clemente Sánchez manifiesta un gran respeto por la conciencia personal y afirma, citando a 
La conciencia de ser pecador va ligada a la existencia misma del hombre. El hombre nace con el pecado a cuestas. Es la herencia de Adán y Eva. Lo expresa muy bien Juan Martínez de Almazán: «Por quanto el uiejo Adan consintiente a la muger enganada del antiguo serpiente gusto la maçana uedada e traspaso a todos aquellos que uenimos despues del manjar tossicado e de muerte, por la amargura del qual todos somos concebidos e nascidos en pecados, por el uenino de aquel gusto todos fuimos conficionados e fechos mortales» ${ }^{85}$.

De esta consideración de la inclinación original al mal, que se hace efectiva con el uso de la razón, se pasa a tener miedo al conocimiento, al saber más allá de lo que cada uno debe saber por razón de su estado o profesión ${ }^{86}$; de ahí también, la insistencia de los pastoralistas en que el confesor no se exceda en el interrogatorio, especialmente sobre los pecados de lujuria, no sea que enseñe nuevos modos de pecar, desconocidos hasta entonces por el penitente. Lo expresa así André Dias: «E acerca desto [se refiere al pecado de lujuria] ha de ser auisado el confessor que algunas cosas deue dexar de preguntar al penitente, en las quales entiende que no sabe pecar, porque de otra manera seria dar ocasión que alli adelante pecasse en ellas» ${ }^{87}$. Ya hemos señalado antes cómo Martín Pérez pide mesura al confesor en el interrogatorio sobre el pecado de lujuria ${ }^{88}$. Alfonso Fernández de Madrigal opina que «el sacerdote deue ser muy discreto cerca del preguntar... especialmente en el peccado de la luxuria e cerca de las maneras de los engaños que fazen en comprar e vender... ca faziendo ansi enseñaría

santo Tomás de Aquino, que actuar contra conciencia es la primera manera de que un pecado venial pase a ser mortal (Sacramental, f. 32v). De ahí que Clemente Sánchez (Ibid., f.119) sea partidario de que, si el penitente sabe la forma de confesarse y la sigue bien, el confesor se limite a darle la absolución. De hecho, es cierto que solía ser el confesor quien llevaba la iniciativa de la confesión desde el primer momento; pero, en genreral, los autores no veían con buenos ojos esa práctica habitual. Juan Martínez de Almazán se lamenta de que los cristianos simples se asienten al pie del sacerdote confesor como canes mudos que no pueden ladrar (Ms S, f. 82ra). Por su parte, el Tostado opina que no se debe preguntar por sistema, sino sólo cuando el confesor advierte que el penitente es ignorante o que está en un error (MS BNMadrid 4202, f. 105va). Pero el más tajante en este punto es Bartolomé Talayero, el cual considera que es un error muy peligroso realizar la confesión a base de preguntas (Ms $10571 \mathrm{BN}$ Madrid, f. 2r-v). No obstante, también estos autores son conscientes de que, dada la ignorancia generalizada de los que se acercan a confesar, se hace imprescindible el interrogatorio del confesor con objeto de salvar la integridad de la confesión.

${ }_{85}$ Ms S, f. $81 \mathrm{vb}$.

${ }^{86}$ En el ámbito de la fe religiosa, los laicos no son obligados a un conocimiento explícito; les basta con «creer implícitamente y en una suma, la qual es creer todo aquello que cree la sancta y catholica yglesia. Ni deuen mas inuestigar de los articulos de la ffe» (Libro de confesión de Bartolomé TALAYERO, ms BNM 10571, f.73r). En términos parecidos se expresa Clemente Sánchez (Sacramental, ff. 11v2v. Cf. J. M. Sото RÁBANOS, «La ignorancia del pueblo cristiano, un obstáculo para el diálogo interreligioso», Diálogo filosófico-religioso entre cristianismo, judaísmo e islamismo durante la edad media en la Península Ibérica (Brepols, 1994), 99-116.

87 Incunable 1007, f. 5r.

88 Ver texto correspondiente a nota 17. 
muchas maneras de peccar a los confessantes, las quales ellos antes non sabian ${ }^{89}$. Bartolomé Talayero, que no es partidario de fundamentar la confesión en el interrogatorio del confesor, da también testimonio de esta regla general de mesura a sensu contrario, al conceder que el confesor, en el caso de que un hombre casado, por guardarse más de pecar, le demandare si hay otras maneras de pecar el marido con su mujer, hace bien en responder, pues se trata de un fin honesto, como es el de guardarse de pecar ${ }^{90}$. Una excepción que confirma la regla, que subyace en el ejemplo, de no enseñar nuevas maneras de pecar.

De otra parte, se observa una cierta objetivación del pecado. El pecado es algo que está ahí, a disposición; es algo que, según los conocimientos de cada cual, se puede tomar o dejar; no está simplemente en la conciencia del individuo creyente respecto a su relación con Dios y a sus deberes con el prójimo y consigo mismo, sino también fuera de ella.

En cierto modo, se reconoce que la ignorancia protege del pecado, en tanto en cuanto por el saber se puede aprender a pecar. El pecado no sólo se comete, sino que antes se descubre, bien sea con la edad, llegados al uso de la razón, bien sea con el aprendizaje. De ahí que unos estados u oficios sean más o menos seguros que otros. Por ejemplo, el mercader, al que se supone hombre avisado, se sitúa entre los oficios peligrosos ${ }^{91}$, y el campesino, al que se tiene por rudo e ignorante, se halla en el estado más seguro, o sea, menos expuesto a pecar $^{92}$. Martín Pérez distingue tres tipos de oficios, siguiendo un criterio de utilidad moral y material: malos, con daño para sí y para el prójimo, como las mujeres del mundo y los histriones; mixtos, en los que a veces hay provecho, a veces no y a veces hay más daño que provecho, como los que venden pinturas, polvos, tocas, yerbas, golosinas, y los mendigos; y provechosos, para las almas, como es el oficio de los clérigos, y para los cuerpos, como lo es el de los labradores ${ }^{93}$.

Esta teoría, que implica sin duda una clara desconfianza hacia el hombre, se justifica en la historia misma de la humanidad, en la realidad del día a día. Mu-

89 Ms. 4202 BNMadrid, f. 105va.

90 Ms BNM 10571, ff.52v-53r.

91 Aunque no figura tan abajo como en la visión de Túndalo. Cf. Adriana ZIERER, «Paraíso versus inferno: a visão de Túndalo e a Viagem Medieval em busca da Salavação a alma (séc. XII)», Mirabilia. Revista de História Antiga e Medieval, 2 (enero, 2003), 137-162; juicio sobre el mercader en p. 147.

92 He aquí el testimonio de Clemente Sánchez (Sacramental, f. 128r): «E commo quier que estos [labradores] pecan en muchas cosas et en diuersas maneras, enpero la vida destos es mas segura».

93 Libro de las confesiones, II, 133, p.443: «Muchos son los los otros estados en que biven los omes, que non se podran contar por menudo, enpero tomaras una pequeña doctrina. Dellos son omes que biven en ofiçios en que non ha pro ninguna e ha siempre en ellos daño de si e de su christiano. E otros omes "hy" que tienen ofiçios otros, en que a las vegadas han provecho e a las vegadas non han provecho e a las vezes ay mas daños. E ay otros que biven de ofiçios que son para pro de si e de sus christianos». Luego va exponiendo el tema por extenso en los capítulos 134-169, pp. 443-490. 
chos autores de este tipo de obras van más allá de la simple consideración de la debilidad moral del hombre y no pierden la ocasión para describirnos el lamentable estado moral de la humanidad y de la Iglesia cristiana ${ }^{94}$.

En líneas generales, se puede afirmar que en esta literatura hay una especie de objetivación del pecado, como si el pecado vagara por ahí como una presa suelta, dispuesta a ser cazada por quien sabe cazar. La conclusión viene dada: quien sabe pecar, puede pecar y peca de hecho; quien no sabe pecar, no peca.

\section{Clases de pecados}

Los tratados de confesión se elaboran con referencia exclusiva al pecado actual. El pecado original apenas es objeto de atención; se le menciona de pasada con la doble finalidad de recordar el pecado de Adán y Eva en el paraíso y celebrar su perdón total, su borrado, por la redención de Jesucristo, que se activa en cada hombre con la recepción del bautismo. Pero, al tiempo, se lamenta el hecho de que el hombre desde aquel momento está inclinado al mal y en cuanto puede, es decir, en cuanto alcanza el uso de la razón, peca ${ }^{95}$.

Son muchas las maneras de pecar y cada día los hombres inventan nuevas, pero todas ellas se reducen a los siete vicios o pecados capitales o mortales, que se contienen en la dicción saligia, dicción mnemotécnica que usan la mayoría de los autores pastoralistas y que se convierte en la palabra mágica, porque en torno a ella giran el pecado, la penitencia y, lógicamente, los tratados o manuales de confesión ${ }^{96}$. La invención de nuevos pecados afecta especialmente al de lujuria. Lo dice castizamente el Tostado al tratar sobre la manera número doce de caer en la lujuria, que es «dormir varón con mujer no por ley acostunbrada de Dios e de la razon ordenada en alguna otra manera, las quales muchas son e cada dia la malicia de los omnes busca mas e fallalas» ${ }^{97}$.

Interesa destacar, en cuanto al uso de la expresión pecados o vicios capitales o mortales, que la denominación de pecado mortal no siempre responde a la gravedad de mortal. Lo he indicado antes, al examinar el tractatus de confessione de Sebastián de $\mathrm{Ota}^{98}$. Los dichos pecados mortales pueden ser graves, más

94 Cabe recordar el De statu et planctu Ecclesiae de Álvaro Pelayo (ca. 1280-1349).

95 Sacramental, f. 102v: «La rayz del qual [se esté refiriendo al pecado venial y se aplica con más motivo al mortal] queda en el omne despues del bautismo».

96 «Dat septem vitia hec dictio saligia». Así el Manipulus de Guido DE MonTe Roterio, f. 183vb. El Libellus informatorius, f. $34 \mathrm{va}$, omite «hec»: «Continentur autem in ista dictione: saligia, vnde versus: dat septem vitia dictio saligia».

97 Ms. 4202 BNMadrid, f. 107rb.

${ }_{98} \mathrm{Al}$ ejemplo del pecado de ira puesto entonces, cabe añadir uno relativo a la avaricia: «Si auarus fuit in non largiendo pauperibus quos uidit in necessitati notabili, mortale; ... veniale, si aliis pauperibus quibuscumque non tribuit etiam de hiis quae sibi non superfluunt» [Si fue avaro en no socorrer a los 
graves, o leves, según las circunstancias. En toda su entidad llevan la categoría de pecados mortales, pero las circunstancias de la acción y del actuante dirán si lo son o no.

La primera división del pecado actual se establece entre el mortal y el venial. Al venial no se le concede importancia y ocupa poco espacio, pero la distinción es decisiva. Al sacerdote confesor se le exige justamente que sepa discernir los pecados, entre lepra y lepra, separar los mortales de los veniales. Martín Pérez añade a estos el pecado criminal: «E conviene saber que ay tres maneras de pecados, ca ay pecados veniales e pecados mortales e pecados criminales», en referencia a los delitos «sobre que el derecho pone penas» Los criminales son todos mortales, en cambio no todos los mortales son criminales, «ca non son todos tan graves» ${ }^{99}$. Es decir, que los criminales son una especie de los mortales, los más graves.

A su vez, la consideración del pecado como mortal o venial es altamente delicada; y los autores suelen manifestar mucha cautela, al menos en teoría ${ }^{100}$, porque luego, a la hora de especificar, de enumerarlos y clasificarlos dentro del cuestionario de la confesión misma, se explayan en la consideración de los pecados mortales, de manera que apenas dejan sitio para los veniales ${ }^{101}$. Martín Pérez propone varias reglas para tratar de diferenciarlos, pero advierte que no se puede llegar a conocer todos por menudo ${ }^{102}$. Su postura está conforme con la teoría de que siempre cabe inventar nuevos pecados, aunque las raíces sigan siendo las mismas siete; es decir, que todas las maneras de pecar, las que sean, hacen relación a uno u otro de los siete pecados capitales: son ramos/ramas, hijos/hijas y descendientes múltiples. Para Clemente Sánchez «los pecados mortales son muchos e en diuersas maneras que non se pueden contar» ${ }^{103}$.

Dentro de los mortales, los hay muy graves, criminales, enormes, casos especialísimos, casos reservados, simplemente graves y más o menos feos ${ }^{104}$, ca-

pobres en situación de necesidad notable, el pecado es mortal;... es venial, si no acudió en socorro de otros pobres, habiendo cuenta incluso de los bienes no supérfluos].

${ }_{99}$ Libro de las confesiones, III, 43, p. 582.

100 Raimundo de Peñafort afirma que no se debe ser pronto a estimar como mortales cualesquiera pecados; que debe constar por escritura cierta que lo son; opinión que influye sin duda en los autores posteriores.

101 Sebastián Ota acompaña el recorrido por las ramas de los pecados capitales con la indicación de si es mortal o venial.

102 Libro de las confesiones, 3. 44-46, pp. 582-597.

103 Sacramental, f. 103r.

${ }^{104}$ La nota de fealdad, aplicada de modo general al pecado, es de uso común. Pero aquí quiero referirme a una aplicación concreta respecto a determinados pecados, que causan más vergüenza en razón de su fealdad, fuera ya de su mayor o menor gravedad, pecados en los que el confesor, como nota Alfonso Fernández de Madrigal, deberá ayudar al penitente para que supere la vergüenza «si cerca de algund pecado muy feo los vieren dubdar faziendoseles grande afliction en lo dezir» (Ms. 4202 BNMadrid, f. 105va). 
lificaciones que suelen usar los autores pastoralistas y que van señalando en el recorrido de los pecados. De otra parte, muchos tratados suelen ofrecer los casos reservados, al menos los reservados al obispo, es decir, aquellos pecados de los que los simples sacerdotes confesores no pueden absolver sin encomienda especial del papa o del obispo, por consideración a su gravedad. La reserva de pecados varía con el tiempo. Martín Pérez señala cincuenta y cinco casos de excomunión mayor con la indicación de si el caso es reservado al obispo o al papa. Dieciséis responden al derecho antiguo, recogido en las Decretales de Gregorio IX básicamente; veinte son del Libro Sexto de Bonifacio VIII; y diecinueve se contienen en las constituciones de Clemente $\mathrm{V}^{105}$. El autor del Libellus informatorius recoge cuarenta y cuatro casos, conformándose al libro así llamado Repertorium iuris ${ }^{106}$. Para Alfonso Fernández de Madrigal hay cuarenta y seis casos reservados, cuarenta son del obispo y seis del papa ${ }^{107}$. Además, el obispo podía y solía hacer comisión de sus casos, pero si esta encomienda era genérica se entendía que era válida para todos, salvo para cinco, cuya encomienda debía ser específica: «Otrosi es de saber que quando el obispo dize a algun clerigo: yo te comito todos mis casos, puede aquel clerigo en todos los casos del obispo absoluer, saluo en cinco... aunque el obispo cometa sus casos non se entiende destos saluo de los que nombro en special» ${ }^{108}$.

La mayor o menor gravedad del pecado viene dada en primer lugar por la propia entidad del acto y en segundo lugar por las ocho características o circunstancias que afectan al pecado y al pecador, que se resumen en versos como los siguientes: «quis, quid, ubi, per quos, quoties, cur, quomodo, quando; quilibet observet animae medicamina dando» (quién, qué, donde, por medio de quiénes [colaboradores], cuántas veces, por qué, de qué modo, cuándo) ${ }^{109}$; o sea: sujeto, objeto o materia, lugar, mediación, cantidad, razonamiento, modalidad, tiempo. Esta atención a las circunstancias acompaña siempre a la confesión, se interrogue o no al penitente. El confesor las tendrá en cuenta para estimar la gravedad del pecado e imponer la penitencia adecuada a pecado y pecador ${ }^{110}$.

105 Libro de las confesiones, I, 2-7, pp. 16-34.

106 Ms Escorial d.IV.2, f. 43rb-vb: «Vigessimum nonum capitulum est de casibus pro quibus est ad episcopum recurrendum secundum quod in iuris repertorio, id est, in illo libro qui sic dicitur, continetur...».

107 Ms BNM 4202, ff. 130va-131ra.

108 Ibid., f.131rb.

109 Así están en el Tratado de Juan Martínez de Almazán (Ms París, f. 163ra-rb). Coincide con la formula del Libellus informatorius, f. 34va-vb. Guido de Monte Roterio (Manipulus, f.179rb), en lugar de observet pone attendat, que no cambia el sentido de la frase. Sebastián Ota pone estos versos de forma ligeramente distinta: «Quid, quis, vbi, quantum, cur, quibus, quomodo, quando» (Incunable Sevilla, f. 3r).

110 Martín Pérez (Libro de las confesiones, 3, 43; p. 582) considera tres clases de pecados: veniales, mortales y criminales, reservando estos últimos para los delitos: «E conviene a saber que ay tres maneras de pecados, ca ay pecados veniales e pecados mortales e pecados criminales... Pecados criminales son aquellos sobre que el derecho pone penas corporales e espirituales, e de que el pecador en juyzio puede ser acusado e a pena corporal o espiritual condenado». 
Los manuales de confesión tratan indistintamente de los siete vicios capitales, de los siete pecados mortales y de las siete raíces de los pecados. Señala Jean Delumeau que por este tiempo ensayaban los teólogos distinciones y clasificaciones varias sobre el pecado y sus raíces ${ }^{111}$. En efecto, así se refleja en los tratados de confesión, pero no hay claridad en el tema. A veces el vicio es raíz, a veces es pecado; a la vez, un pecado es a un tiempo pecado y raíz de pecados, de modo que raíz, vicio y pecado pueden significar o no lo mismo. Cómo se ha de entender en cada caso, se deduce del contexto.

Los pecados que suelen ocupar más espacio son los de avaricia y lujuria, por este orden. Sin embargo, el primer pecado o vicio capital es la soberbia, aunque no sea en el que más se detengan los tratadistas. Tampoco es la lujuria el pecado al que estos manuales prestan una atención más detallada ${ }^{112}$, si bien, me parece que lo contemplan con más recelos y cautelas que a los otros seis. Así se explica, por ejemplo, el consejo a los confesores de que tengan especial prudencia en interrogar sobre la lujuria, no sea que enseñen pecados nuevos en la materia. En cuanto a la avaricia, la razón de extenderse más en ella viene dada por dos de sus hijas: la usura y la simonía. Martín Pérez afirma que el confesor, en el interrogatorio que conviene hacer después de oír la confesión del penitente, debe iniciar las preguntas por los pecados de lujuria y avaricia «por razon que en dos maneras de pecados se enbuelven mas los omes, conviene saber luxuria e avariçia, por esto conviene que demandes primero destos, e primero de la luxuria» ${ }^{113}$. Para Bartolomé Talayero los tres pecados principales, a los que se reducen los demás son: lujuria, soberbia y avaricia, por lo que a ellos se orientan las tres partes de la satisfacción: ayuno contra lujuria, oración contra soberbia y limosna contra avaricia ${ }^{114}$.

\section{Pecados que se deben someter a la confesión}

Es ésta una cuestión que los tratados despachan en pocas líneas. Por supuesto, no cuenta el pecado original, que no da juego después del bautismo. Los autores están de acuerdo en que se deben confesar todos y cada uno de los pecados mortales con las circunstancias que mudan la especie, pues esas circunstancias hacen que ese pecado sea distinto. En cuanto a las que no mudan la especie de los pecados, Guido de Monte Roterio, en el siglo XIV, nos dice que los doctores no están de acuerdo; para unos, su confesión es de necesidad, para otros, es útil y conveniente, pero no de necesidad ${ }^{115}$. Sebastián de Ota, a fi-

\footnotetext{
111 O.c. en nt. 4, p. 214-215.

112 El Tratado de confissom de CHAVES es una excepción que confirma la regla.

113 Libro de las confesiones, 1.19, .47.

114 Ms BNM 10571, ff. 18v-19r.

115 Manipulus curatorum, f. 178-180.
} 
nales del siglo $\mathrm{XV}$, afirma que se deben confesar expresamente las circunstancias si agravan el pecado en grado notable, sin teorizar sobre la cuestión de si mudan la especie o no. Sin embargo, a la hora de exponer el modus confitendi, suelen hacer aparición todas las circunstancias que acompañan a los pecados, incluidos los detalles de menor monta, atendiendo a las ocho circunstancias ya mencionadas: quis, quid, ubi, etc.

Por lo que se refiere a los pecados veniales, se observan posturas diversas en cuanto a la exigencia de su confesión. El gran maestro de los autores pastoralistas, Raimundo de Peñafort reconoce que la mayoría de los teólogos considera no necesaria la confesión de los pecados veniales. No obstante, él mismo, cuando trata de la práctica, se muestra rigorista en este punto y nos manifiesta sus preferencias por la opinión minoritaria, a la que cree más segura, según la cual se deben confesar también los pecados veniales ${ }^{116}$.

Martín Pérez pone tres casos en los que hay obligación de confesarlos: primero, cuando hay duda de si el pecado es mortal o venial ${ }^{117}$; segundo, para cumplir la constitución lateranense Omnis utriusque sexus fidelis; tercero, cuando el venial pasa a ser mortal por alguno de los siguientes motivos: gran deleite, mucho consentimiento en su comisión, repetir un pecado hasta convertirlo en habitual ${ }^{118}$.

Guido de Monte Roterio no se preocupa de la confesión de los veniales, que se pueden borrar de muchas maneras sin la confesión, Entre ellas cita como dudosa la bendición del sacerdote al final de la misa: «et idem credo, non tamen, assero, de benedictione sacerdotis, quae fit in fine missae» ${ }^{119}$.

Clemente Sánchez se acoge al hecho securior, no simplemente a la opinio securior ${ }^{120}$, por lo que aconseja la confesión de algunos veniales «que son menores e non tan vsados». Los veniales habituales «se tornan en mortales» y se deben confesar; mientras que los veniales muy pequeños «se perdonan e quitan en muchas maneras» ${ }^{121}$. Clemente sostiene el consejo por ser lo más seguro y para evitar riesgos. Opina que para algunos casos de pecados veniales sí se re-

116 Summa de poenitentia et matrimonio, lib. 3, tit. 34, § 20 (Roma, 1603, p. 454).

117 Como era habitual, se atiene a la opinión más segura.

118 Libro de las confesiones, 3.47, pp. 598-599. Pocos años después de Martín Pérez, Pedro de Cuéllar, obispo de Segovia, en su libro sinodal promulgado en 1325, sobre la confesión de los veniales se limita a decir que se borran de muchas maneras fuera de la confesión: por la comunión, el agua bendita, los ayunos, las limosnas, el Paternoster, los golpes de pecho, la confesión general del principio de la misa, la bendición del obispo [no menciona la del sacerdote], la extremaunción. La lista no parece cerrada, sino ejemplificativa. Advierte, como Martín Pérez y la doctrina de entonces, que un venial habitual pasa a ser mortal.

119 Manipulus, f. $178 \mathrm{vb}$.

120 Actitud que, a mi entender, pone de manifiesto una dosis no pequeña de liberalidad moral por parte de este autor, aunque se sitúe dentro de la ortodoxia de lo securior.

121 Sacramental, ff. 102v-103r. 
quiere su confesión especial, mientras que para otros basta la confesión general ( $s i n$ especificar, pero se refiere sin duda a la fórmula recitada en privado), y en otros no se precisa ni la una ni la otra. Por eso, termina diciendo, lo más seguro es confesarlos siempre. Como en otras cuestiones, Clemente Sánchez da aquí muestras de su imprecisión.

En realidad, no señalando los teólogos esta obligatoriedad de forma unánime, ni los juristas canonistas podían hacerlo ni los sacerdotes curados tratar de aplicarlo de forma imperativa. La puerta quedaba más o menos abierta en uno u otro sentido. Si bien, esto servía más a los confesores que a los penitentes, en líneas generales, dado que, en su mayoría, no era peritos en estas cuestiones.

En conclusión, que sólo el pecado mortal es materia obligatoria de toda confesión. El pecado venial no impone de por si obligación de someterlo a la confesión oral; pero, excepcionalmente, puede imponer dicha obligación, por motivos ajenos al pecado en si en cuanto venial; por ejemplo, para cumplir con la obligación anual de confesarse, que tiene vigencia por si misma, independientemente de que se haya cometido o no pecado mortal. La confesión en ese caso es para cumplir con la obligación y, consecuentemente, para no pecar mortalmente, dado que el incumplimiento de la obligación de la confesión anual se considera pecado mortal, lo que significa que obliga sub gravi. Decir también a este respecto, que incluso los autores que no tratan de propósito esta cuestión dejan ver a lo largo y ancho de su exposición que solamente el pecado mortal induce la obligación de acudir a la confesión oral sacramental.

\section{La gran circunstancia de la notoriedad}

No me he detenido antes en consideraciones sobre las circunstancias que acompañan a los pecados; pero ahora, en epígrafe aparte, quiero resaltar una que me parece digna de ser tenida en cuenta especialmente, aunque no esté incluida con entidad propia entre ellas. En verdad, no es una de las ocho, pero afecta normalmente a varias. Me refiero a la notoriedad del acto pecaminoso.

La apariencia, el escándalo, el matiz de exteriorización, que se da en los pecados externos, resulta ser una circunstancia agravante objetiva, que se tiene en cuenta para la estimación moral y, en consecuencia penal, del acto pecaminoso. En cierto modo se puede hablar de una socialización del pecado, de una juridización, de una desteologización.

Hasta la baja edad media, primaban como pecados para la Iglesia los actos externos y notorios que se consideraban diametralmente contrarios a la fe, por los que se imponía la pena de exclusión de la comunión eclesial, de la societas christiana, entendida como una sociedad de santos, mientras que los demás in- 
cumplimientos quedaban, en cierta manera, entre el hombre y Dios, sin intervención obligada de la Iglesia.

Ahora se pasa a la obligación de incluir en el poder de las llaves delegado a la Iglesia en sus representantes los pecados todos, con inclusión de los pecados internos, de pensamiento y deseo. Diríamos que ahora, respecto al sacramento de la penitencia y a la obligación de confesarse, se peca de pensamiento, palabra y obra; y todo pecado ante Dios lo es también ante la Iglesia. Pero se mantiene, no obstante, la consideración de que el pecado hecho acto externo reviste una importancia que no tiene ese mismo pecado si queda dentro: el rencor u odio que no se exterioriza, el deseo criminal o impuro que no se lleva a cabo, por muy grave y mortal que pueda ser cara a Dios, no entra en la categoría de los crímenes, pecados enormes o casos especialísimos. O sea que, ante la Iglesia, un pecado de pensamiento o de deseo no podía ser considerado un pecado muy grave por falta de exteriorización.

Ello se pone de manifiesto indirectamente, cuando a la notoriedad se le hace figurar como razón y fundamento de que permanezca aún en vigor la forma penitencial pública: «E esta penitencia publica se deue de dar por quatro razones. La primera por quanto el pecado que es publico aya melezina publica. La segunda que aquel que grauemente peca deue padescer grand confusion e verguença. La tercera porque sea enxemplo e castigo a los que lo vieren. La quarta porque los que lo vieren e supieren ayan manera de se arrepentir e non desesperar por ningunos e graues pecados» ${ }^{122}$.

Se observa en el texto citado del Sacramental gran paralelismo entre gravedad y publicidad. Se entiende que el pecado externo supone un mal ejemplo en la asamblea de santos, o sea, en la iglesia. La publicidad añade al pecado un plus; le añade el escándalo de no presentarse con el traje de boda. Se trata de algo más que de un pecado; se trata de un delito, de un crimen. De ahí que la notoriedad esté presente y justifique los casos reservados.

\section{Control a través del pecado, de la confesión y del perdón}

Teniendo en cuenta el castigo público grave, que se impone a los que no cumplen con la obligación de la confesión-comunión anual, se percibe la importancia que la Iglesia dio desde entonces al hecho de la confesión oral de los pecados. Significaba un control total de sus fieles, tanto ideológico y psicológico como social y político, con lógicas repercusiones en la conducta de los mismos, no sólo dentro del ámbito de la conciencia, conforme a la fe cristiana, sino también en el terreno de la vida familiar y social vecinal: rela-

122 Sacramental, f. 99v. 
ción marido-mujer, padres-hijos, vecinos con vecinos y extraños; aspectos laborales y profesionales, con sus derivaciones económico-fiscales; aspectos recreativos y festivos, etc. Nada escapaba a este control anual, sin perjuicio del control cotidiano que el curado ejercía, o debía ejercer, mediante la atención a los enfermos, los rezos de las horas, las misas dominicales con su predicación-enseñanza, o con sermón en regla, el ejemplo de vida, la asistencia al necesitado. Algo así como el examen final anual de curso en una carrera que dura la vida toda.

En torno al perdón del pecado, aunque su tratamiento particularizado queda fuera de este trabajo, me permito una breve anotación, que creo pertinente para lo que vengo tratando. En este tipo de obras me parece ver que se hace una clara distinción entre el perdón de Dios y el perdón de la Iglesia; no en el sentido de que puedan contradecirse, lo que también podría suceder, sino en el sentido de que se dan en momentos distintos y, en parte, de distinto modo. Dios atiende a la contrición, o sea, a la interioridad, a la autenticidad, y no puede ser engañado. Por eso, pueden afirmar que el perdón de Dios es anterior al hecho mismo de la confesión. La iglesia debe atender a la manifestación del arrepentimiento, y reconcilia al penitente de cara a la iglesia misma, admitiendo que puede ser engañada.

Pero esta acción se teoriza de tal manera que el perdón, ya concedido por Dios ipso facto a la contrición, al arrepentimiento del corazón, no sea efectivo hasta que la iglesia lo ejecuta a través de su ministro autorizado. Queda latente, a condición de que la iglesia ejerza el poder de las llaves; y se entiende que si no se realiza esta segunda parte, salvo que el cristiano en cuestión se viera imposibilitado de llevarla a cabo, no se puede hablar de contrición, ni de perdón divino efectivo consecuentemente; siempre de cara a la iglesia. Se exige el registro del perdón.

Además, el perdón no es necesariamente total; sólo lo es en cuanto a la culpabilidad. Así, el pecado que se ha confesado no vuelve, pero queda el reato, la expiación, que responde de una parte al cumplimiento de la satisfacción o pena impuesta, llamada también penitencia, y, de otra, al grado del arrepentimiento. Cabe, pues, siempre la duda de si se ha satisfecho de modo pleno. Aquí viene bien la idea del purgatorio, como lugar de expiación, como medio de conseguir la limpieza total que es necesaria para llegar a la visión divina, al cielo. Pero el purgatorio, tal como aparece en algunos tratados de confesión, es una morada de tránsito a esquivar. Sin dejar de ser considerado, en cierta medida, un espacio intermedio entre infierno y paraíso, se pone el énfasis en la parte negativa: el sufrimiento; no en que es un peldaño para el cielo, que sería una visión positiva, de esperanza. Bartolomé Talayero enfatiza el dualismo cielo e infierno; no presenta el purgatorio como un espacio intermedio. Es una morada del infierno, en el que ocupa la segunda de sus cuatro concavidades. Claro que suaviza un 
tanto su posición al matizar que la cuarta cavidad o lugar es el infierno por excelencia, «como todo junto se llama asi» ${ }^{123}$.

La doctrina sobre el purgatorio compagina muy bien con la nueva práctica penitencial, en la que se impone la satisfacción al arbitrio del confesor. La creencia en el purgatorio, como lugar de expiación a evitar, sirve para agilizar los perdones, para predicar y fomentar las limosnas y para impulsar las donaciones a iglesias e instituciones religiosas, con la excusa de alcanzar el perdón de los pecados del modo más completo posible, de hacer méritos para entrar directamente o casi en el cielo.

Este es a grandes rasgos el panorama que nos ofrecen los manuales de confesión en torno al pecado y a sus principales especies contenidas en la palabra mágica saligia.

123 Ms BNM 10571, ff. 20r-22r. 